\title{
Subjektivita a semiabstraktné prvky v starej čínskej malbe tušom
}

\author{
Daniela Zhang Cziráková \\ Ústav orientalistiky Slovenskej akadémie vied, Klemensova 19, 81103 Bratislava
}

\section{SUBJECTIVITY AND SEMI-ABSTRACT FEATURES IN THE TRADITIONAL CHINESE PAINTING}

\begin{abstract}
Chinese art is often characterised by its subjectivity, the freedom in the brushwork, rather than descriptive realism. There are some specifics in the history of Chinese painting, which made it be very different from Western tradition. Lack of western one angle perspective, lack of shading, stress to the brush strokes, caused the misunderstanding between Western and Eastern art in history, but subjectivity of Chinese ink painting became a strong inspiration to Western abstract artists. Chinese painting in its history came times to times very close to abstraction.

In China, artists started very soon use their brush to express their own deepest feeling rather than to capture reality. Painting was much more self-expression of the artist than the formal likeness. In the article, I pay my intention especially to some styles in Chinese painting, for example, to xieyi, which means exactly "writing ideas", I involve to semi-abstract tendencies in the history of Chinese ink painting, some authors, who are interesting from the point of view subjectivity.

There are authors almost leaving the position of objective representation in the painting, even proud to be independent from objective reality, to non-likeness of their works, authors, creating semi-abstract paintings, using rough strokes of brush to create their inner world, escaping from the reality. My article presents those tendencies in traditional Chinese painting in the history of Chinese art. I do not try to deny the strong realistic tradition in the Chinese painting; I only present the strong position of subjectivity in the history of Chinese ink painting, in the literati-painters, zen Buddhists painters or other non-orthodox spirits in China. We can find the opinions preferring subjectivity to formal likeness even in the eldest philosophic and art theories in China, stressing shensi 神似 to xingsi 形似.
\end{abstract}

KEY WORDS sinology; Chinese art; Chinese painting; subjektivity

ABSTRAKT Č́nske umenie je často charakteristické skôr svojou subjektivitou, slobodou v práci s tušom ako popisným realizmom. Sú určité špecifiká čínskeho maliarstva, pre ktoré je odlišné od západnej umeleckej tradície. Absencia západnej perspektívy jedného uhla, chýbajúce tieňovanie, dôraz na tahy štetca spôsobili v minulosti nedorozumenie medzi Západom a Východom, ale subjektivita čínskej malby tušom sa stala silnou inšpiráciou pre západných abstraktných umelcov. Č́nska malba sa v jej dejinách ocitla vel’mi blízko k abstrakcii.

V Číne začali umelci velmi skoro uprednostňovat využívanie štetca na vyjadrenie najhlbších osobných ideí pred zachytením skutočnosti. Malba bola ovela viac o umelcovom sebavyjadrení než o formálnej podobnosti. V článku venujem pozornost̉ hlavne niekolkým štýlom v čínskom maliarstve, napríklad xieyi, čo doslovne znamená „záznam ideí“. Zaoberám sa semiabstraktnými tendenciami v dejinách čínskej malby tušom, niekolkými autormi, ktorí sú zaujímaví hlavne z pohladu subjektivity.

Niektorí autori takmer opustili pozíciu objektívneho zobrazovania, boli dokonca hrdí na nezávislost’ od objektívnej reality, na nepodobnost’ ich prác, autori, ktorí používajúc nedbalé tahy štetca vytvorili semiabstraktné diela, unikali z objektívnej reality do svojho vnútorného sveta. Nepopieram silné realistické tradície v čínskej malbe, vo svojom článku prezentujem silnú pozíciu subjektivity v dejinách čínskej malby tušom, či už v tvorbe maliarov-literátov, zen-buddhistických maliarov alebo iných neortodoxných osobností v Číne. Dokonca aj v najstarších filozofických spisoch či vo výtvarno-teoretických dielach môžeme v Číne nájst’ názory uprednostňujúce subjektivitu voči formálnej podobnosti, zdôrazňujúce shensi 神似 oproti xingsi 形似.

KLUUČOVÉ SLOVÁ sinologie; čínske umenie; čínska malba; subjektivita 


\section{ZÁKLADNÉ ČRTY ČÍNSKEJ MALBY TUŠOM}

Mal'ba je jedným z reprezentatívnych ukazovatelov čínskej kultúry a celého čínskeho duchovného sveta. Popri poézii, ktorá narába s jemnými odtieňmi významov, sa aj čínska malba stala prostriedkom, pomocou ktorého umelci vyjadrovali svoje pocity prostredníctvom zobrazovania vonkajšej reality. Podla taoistickej filozofie bolo stotožnenie sa s predmetom poznávania jedným zo spôsobov poznania. Hoci k oslobodeniu sa maliarstva od jeho reprezentatívnej funkcie, ktoré vytvorilo podmienky pre potenciálny príklon $\mathrm{k}$ autorskému sebavyjadrovaniu, prišlo neskôr ako u iných umeleckých žánrov, napríklad kaligrafie alebo poézie, ktoré boli považované za vysoké umenia historicky ovela skôr ako maliarstvo, v neskorších dobách hrala mal'ba vel'mi dôležitú rolu a jej postavenie bolo mimoriadne vysoké.

Čínske maliarstvo možno stručne definovat’ ako jedno z tradičných čínskych výtvarných umení. V priebehu storočí došlo k rozdeleniu čínskej malby na základe zobrazovaného objektu na niekol'ko základných žánrov, ako sú figuratívna malba, ktorej základy sa sformovali v období neskorých Zhou (1046-221 pr. n. 1.), Han (206 pr. n. 1.-220 n. 1.), Severných Wei (386-535); krajinomalba ktorej počiatky sa datujú od obdobia Piatich dynastií (907-960) a k sformovaniu tohto žánra dochádza za dynastie Song (960-1279); malbu kvetov, vtákov a zvierat, ktoré existujú ako samostatné žánre od Sui (580-618) a Tang (618-907) a iné. Po formálnej stránke z hladiska techniky malby možno čínsku malbu rozdelit na malbu „presným štetcom“, gongbi 工筆 a mal'bu xieyi 寫意, čo možno preložit ako „zachytenie vnútornej podstaty“. Čínska mal'ba sa dalej rozlišuje na malbu tušom s využitím farieb, ako aj monochromatickú farbu tušom, ktorá pracuje s nuansami tmavého a svetlého tušu.

Monochromatická mal'ba tušom, ktorej hlavným prúdom bolo xieyi, je malba používajúca výlučne tuš, bez prímesi minerálnych farieb. Jej začiatok sa zvykne datovat do dynastie Tang, kedy sa etablovala ako osobitný štýl. Tento štýl využíva technické možnosti tušu a jeho protagonisti veria, že tušové odtiene od svetlošedej po čiernu dokážu nahradit farby. Preto sa zvykne hovorit, že „tuš má pät farieb“. Význačný maliar a básnik, Wang Wei 王維 (699-761?), žijúci za dynastie Tang, sa vyjadril, že malba tušom, shuimo 水墨stojí najvyššie, neskorší ludia to rešpektovali (Zhongguo meishu cidian, 4). Štýl xieyi alebo vyjadrenie vnútornej podstaty (presný preklad je „Zaznamenat' idey“) sa nesnaží o dosiahnutie vonkajšej, formálnej podobnosti xingsi 形似, ale kladie dôraz predovšetkým na prácu štetca, jeho jednotlivé tahy a ich krásu, pričom často kombinuje výrazové prostriedky mal'by a kaligrafie.

Jedným zo špecifík tradičnej čínskej malby je fakt, že na jednej strane sa nesnažila za každú cenu o zachytenie vonkajšej podoby, vonkajšieho tvaru, no na druhej strane mimoriadne dbala na formálnu dokonalost' umeleckého diela. O jednotlivých líniách určitých obrazov sa hovorilo často ovela viac a častejšie ako o predmete, ktorý zobrazoval. Tieto špecifiká platia predovšetkým pre malbu maliarov-literátov (wenren 文人) ktorí uprednostňovali vel'korysý štýl xieyi, načrtnutia ideí, a monochromatickú mal'bu pred pracnou „farebnou“ malbou. Pravda, podobné názory sa presadili až v neskorších obdobiach, za Tang spontánna tušová mal'ba nestála vyššie nad precízne vykreslenou malbou kolorovanou minerálnymi farbami. Takisto nikdy absolútne neplatila teória o wenren ako o maliaroch tvoriacich výlučne pre vlastné potešenie bez akéhokolvek iného (komerčného) zámeru, čo bol skôr ideálny stav, prax mohla byt (a často aj bola) iná.

Čínska malba vo svojom historickom vývoji mimovolne dospela k vysokej subjektivizácii malby, uprednostňovala expresiu pred formálnou reprezentáciou. V miere slobody, s akou narába s objektívnou realitou, sa dostala velmi d’aleko od objektívneho zobrazovania reality, dokonca možno povedat', že niektoré prvky ako napríklad prelínanie sa malby s písaným textom, kombinovanie rozličných uhlov pohladu a s tým súvisiaca absencia jedno ohniskovej perspektívy, ktoré sa vyskytujú v tradičnej čínskej malbe, sa v západnom výtvarnom umení objavili v rovnakej miere až s príchodom modernizmu. Prirodzene, nemožno popriet' silné realistické tendencie v čínskom maliarstve, ktoré tejto subjektivizácii predchádzali, či existovali paralelne. Vel'ký dôraz sa kladie na prenos ideí, yijing 意境. „Maliarova úloha nie je jednoducho zachytit vonkajšiu formu subjektu. Ovela dôležitejšie pre neho je uchopit jeho esprit alebo esenciu a spravit' ju viditelnou pre diváka. Ked' maliar pracuje na určitej scenérii, rodia sa jeho pocity. Vznikajú myšlienky, ktoré sú tažko vyjadritel’né slovami a miesto slov sú zachytené prostredníctvom obrazov. Toto je prenos ideí. Toto splynutie scenérie a emócii je presne to, čo je označované pod pojmom prenos ideí" (Wang Yao-ting 1996, 17). Pre čínsku malbu je vo väčšine prípadov typická viacohnisková kompozícia, čo znamená, že čiary na obraze sa nezbiehajú do jedného ale viacerých ohnísk. Tento faktor v minulosti do značnej miery spôsobil problémy s akceptáciou čínskej malby medzi západnými umeleckými kruhmi. „Vedecká perspektíva vyžaduje pohlad z jedinej pevnej pozície, a zahŕňa iba to, čo je možné vidiet' $\mathrm{z}$ tohoto jediného bodu. Ak to uspokojuje západnú logickú mysel', pre čínskeho maliara to nestačí; pýta sa, prečo by sme mali sami seba tak obmedzovat? Prečo, ak máme prostriedky zachytit čo vieme, že sa tam nachádza, máme malovat iba to, čo vidno z jediného uhlu pohladu?" (Sullivan 1977, 163). Pre čínskych umelcov bola nepredstavitelná a zväzujúca práve táto diktatúra jediného uhlu pohladu. Zvláštnu rolu v kompozícii často zohrával prázdny priestor, ktorý sa stal dôležitým kompozičným prvkom. Je možné, že to bolo spôsobené vplyvom buddhistickej filozofie. No možno to bolo spôsobené snahou nedopovedat' všetko, nechat priestor pre fantáziu (pre báseň, možno aj pre pochvalné vyjadrenie neskoršieho zberatel'a). Podla Sullivana, „kompozícia v čínskom maliarstve nie je definovaná štyrmi stenami ako európska malba svojim rámom. Naozaj, čínsky maliar tažko uvažuje o ,kompozícii‘ celkovo. Tieto formálne úvahy, ktorým západný maliar venuje tolko pozornosti, berie čínsky maliar privel'mi vol’ne na to, aby si ich dostatočne vážil“ (Sullivan 1977, 163-164).

„Čínske maliarstvo sa zaujíma o odhalenie, ukázanie univerzálnych aspektov, nie o prchavé fenomény. Usiluje sa o vyjad- 
renie vnútornej podstaty, nie o vonkajšiu formu, je to fundamentálne umenie línií a výrazných tahov štetca" (Cahill 1982, 2). Vyvíjalo sa od zobrazovania reality k zachyteniu duchovnej podstaty reálneho sveta, k vyjadrovaniu subjektívnych pocitov, či princípov univerza.

Západná moderná a súčasná malba prešla za posledných asi dvesto rokov vel'kou reformou v umeleckej tradícii. Mnohé diela odhalujú osobné emócie tvorcu. $\mathrm{V}$ malbe sa, počnúc Manetom, Van Goghom, Matissom, Picassom, až po súčasných umelcov, jasne odzrkadluje umelcova osobnost'. Z umeleckých diel je možné výraznejšie vycítit umelcov charakter, ktorý je $\mathrm{v}$ určitom ohlade trochu podobný subjektívnemu faktoru, ktorý môžeme v skrytej forme nájst’ v čínskom maliarstve ovel’a skôr a vo väčšej miere ako v európskom.

Čínska malba používajúc svoje expresívne pôsobiace línie, k statickému obrazu pridala plynúci faktor času. Zároveň do malby vstúpila kaligrafia, pečate a slová básní. Básnický zmysel sa objavuje zároveň s plynutím času. Počnúc Kandinským, niektorí maliari a estetici začínajú v západnom umení neprestajne diskutovat vnútorné vztahy umenia priestoru a umenia času. Možno povedat', že čínska mal'ba z určitého uhlu pohladu už ukázala taký príklad (Deng Fuxing 1986, 23).

\section{MALBA MALIAROV LITERÁTOV A JEJ ŠPECIFIKÁ}

Ako ukazuje predošlá kapitola o teórii čínskej malby, čínska mal'ba začala už od obdobia Šiestich dynastií klást' velký dôraz na spirituálnu konsonanciu, qiyun 氣韻. Malba maliarov-literátov, wenren hua 文人畫, ktorej začiatky sa datujú od dynastie Song, a ktorá zaznamenala vel'ký rozvoj za Yuan (12601368), doviedla tieto výtvarno-teoretické úvahy do logického vyústenia vo svojich dielach. V rámci ich malby dochádzalo približne od obdobia dynastie Song (960-1279) k častému prelínaniu sa malby s kaligrafiou. Tieto dva druhy výtvarného umenia sa vzájomne prekrývali, splývali a ovplyvňovali sa. Samotná malba sa pri vyjadrení formálnej stránky zbavila prísnych požiadaviek na odzrkadlovanie objektívnej reality. Možno povedat', že prostredníctvom kaligrafie sa do čínskej mal'by dostalo aj iné médium a tým bol písaný text. Často šlo o poéziu, ktorá dotvárala atmosféru umeleckého diela. Čínski maliari-literáti používali malbu ako prostriedok na vyjadrenie svojich pocitov, názorov, ideálov. V malbe sa často priamo premietala maliarova osobnost', jeho temperament, morálka a kultivovanost', či jeho momentálna nálada.

Z uvedených faktov je zrejmé, že čínska mal'ba, alebo prinajmenšom jej čast', mali vel’mi blízko k subjektívnemu vyjadrovaniu svojich pocitov a $\mathrm{k}$ sebavyjadreniu prostredníctvom svojich diel a toto sebavyjadrenie často kládli vyššie ako snahu o presné zachytenie objektívnej reality. Názory uprednostňujúce subjektívne vyjadrenie pred vonkajšou podobnostou nachádzame už v najstarších filozofických alebo výtvarno-teoretických spisoch. Čínske maliarstvo, na rozdiel od západného, často zdôrazňovalo vnútornú podobnost' s objektom shensi 神似 pred vonkajšou podobnostou, založenom len na odpozorovaní tvaru objektu xingsi 形似.
Malba literátov, wenren hua sa výrazne odlišuje od profesionálnej, palácovej a ludovej malby. Vel'ký songský básnik, maliar a kaligraf Su Shi 蘇軾 (1036-1101) ju spomínal ako „mal'bu úradníkov“ shi fu hua 士夫畫 a až mingský maliar, literát a výtvarný teoretik Dong Qichang 董其昌(1555-1636) ju nazval pojmom malba literátov wenren hua. Za jej zakladatela je tradične pokladaný tangský maliar Wang Wei. Ako tvrdí moderný výtvarný teoretik Chen Hengke 陳衡恪 (1876-1923), „malba literátov má štyri podmienky: morálne kvality autora, vzdelanie, talent a emócie, názory. Iba ak sú dosiahnuté všetky predpoklady, je dokonalá“. Tento štýl malby zdôrazňuje vnútornú, spirituálnu harmóniu, nestará sa o vonkajšiu podobnost', váži si literárnu a kaligrafickú vyspeloste diela, a tvorbu prenosu ideí, yijing v obraze (Zhongguo meishu cidian, 4).

Starí maliari-literáti v tvorivom procese niekedy zdôrazňovali aj objektívnu realitu, ale takisto sa prostredníctvom subjektívneho vnímania snažili zjednodušit a pozmenit’ objekt mal'by. Často si „požičiavali“ určitý objekt, teda mal'ovali konkrétny predmet, aby prostredníctvom neho vyjadrili svoje osobné pocity. Toto ich geniálne hladanie prekročilo hranice formálnej podobnosti, snažiac sa v najväčšej miere dosiahnut ideálny efekt práce tušu a štetca kdesi medzi podobaním sa a nepodobaním sa. Maliari-literáti často pre potreby malby pretrhali obmedzenia objektívneho videnia predmetu a vyjadrovali sa prvkami založenými na abstraktnej kráse tahov štetca a odtieňov tušu; tu tmavého, tam zasa svetlého, niekde hustého inde riedkeho. Ich línie mohli byt' zvlnené alebo rovné, hrubé sa prelínali s tenkými, dlhé s krátkymi, niekde používali mokré línie, inde zasa suché, rýchle pohyby kontrastovali s pomalými. Relatívne slobodne využívali plochu obrazu. Pri vyjadrovaní celej škály maliarových slobodných a bohatých pocitov, využívali velkoryso, podla vlastnej predstavy bezhraničné, neobmedzené a rôznymi spôsobmi zjednodušené či modifikované tahy štetcom. Štetec tak nasleduje poryvy duše ( $b i$ sui xin yun 筆隨心運). Podla názorov predstavitelov maliarov-literátov, zobrazovanie na základe vnútornej podobnosti (yi xiang zaoxing 意象造型) má vždy hlboký dôvod, nezáleží na tom či vychádza $z$ vnútorných zákonitostí tušu a štetca, alebo z estetických teórii (Lu Hong 1985, 24-25).

Podla Cahilla, „kaligrafické obrazy učencov-amatérov neboli skutočne rýchle alebo zjednodušené interpretácie viac ukončených a kompletnejších obrazov ako boli mal'by najlepších profesionálov. Miesto toho boli viac-menej sebestačnými štruktúrami expresívnej práce štetcom, ktorých vztahy k objektom v prírode boli vždy problematické“ (Cahill 1988, 86-87 - skrátené). Nezávislost’ od objektívnej reality a priznaná subjektivita umelcovej tvorby je v mojich očiach niečo, $\mathrm{k}$ čomu sa európska malba $\mathrm{v}$ takom rozsahu dopracovala až začiatkom novoveku, čoho dôsledkom sú napríklad malby Van Gogha, ktoré sú vzácne práve preto, že vyjadrujú subjektívne pocity autora, jeho pohlad na svet, bez toho, aby boli zviazané s objektívnou realitou. Nemožno vylúčit, že na Západe zbavil mal'bu povinnosti realisticky zobrazovat' objektívnu skutočnost' až vynález fotografie a nemožno si nevšimnút, že aj umelecká fotografia sa v rámci svojich možností snaží uniknút pred vecnou popisnostou. 
Počnúc postimpresionizmom, západné výtvarné umenie, najmä v poslednom storočí, prestáva pocitovat jednoznačnú závislost' od nami vnímanej objektívnej reality ako hlavnú hodnotu umenia. Picassove malby sú inšpirované realitou, ale nekopírujú ju, Pollockov abstraktný expresionizmus uniká pred realitou do svojho vnútorného sveta, do sveta estetiky, krásy a expresivity čiar, podobne ako niektoré diela čínskej kaligrafie, bez ohladu na to, či boli de facto napísané takou rýchlostou, akú anticipuje miera zjednodušenia línií.

Treba však uviest', že maliari-literáti neboli jediní, ktorí uplatňovali zásady subjektivizácie maliarstva. Nemožno zabudnút na maliarov, ktorí inšpirovaní taoizmom, alebo buddhistickými či zen buddhistickými ideami opúštali zaužívané pravidlá malby, ani na neskorších maliarov individualistov, ktorí priviedli čínske umenie na vrchol subjektivizácie a sebavyjadrenie, expresiu, povýšili na najdôležitejší umelecký imperatív.

\section{STRUČNÁ HISTÓRIA ČÍNSKEJ MALBYY A NIEKTORÍ MALIARI, DÔLEŽITÍ Z HLADISKA SUBJEKTIVITY ČÍNSKEJ MALBY}

Aj vel'mi stručné dejiny čínskeho maliarstva sú príliš obsiahle na to, aby sa dali spomenút všetci dôležití autori. V nasledovnom prehlade by som chcela zamerat' svoju pozornost' predovšetkým na maliarov, ktorí vo svojich dielach zašli za hranice objektivity d’alej ako ich súčasníci, ktorí sa v značnej miere pričinili o to, že na čínske maliarstvo sa aj v súčasnosti pozerá predovšetkým z pozície subjektivity zobrazovania, nie z pozície realistickej vernosti zachytenia tvaru predmetu.

Nemám v úmysle popierat' umelecké hodnoty umelcov, ktorí malovali iným spôsobom, ani znižovat smery a štýly malby zdôrazňujúce realistické zobrazovanie predmetov. Svojím velmi krátkym výpočtom sa snažím poukázat na fakt, že čosi blízke abstrakcii bolo v čínskej malbe latentne ukryté vel’mi dlho, a to i napriek tomu, že na abstrakciu sa ešte pomerne nedávno niektorí čínski výtvarní kritici pozerali ako na niečo nečínske, čisto západné a čínskej kultúre cudzorodé, občas aj s negatívnou konotáciou.

\subsection{Najstaršie maliarstvo, obdobie dynastie Han (206 pr. n. 1.-220 n. 1.) a Šest' dynastií (220-589)}

Čínske maliarstvo má svoje špecifiká a dlhú, niekolko tisícročnú tradíciu. Najstaršie doteraz nájdené obrazy pochádzajú z obdobia Bojujúcich štátov (475 pr. n. 1.-221 pr. n. 1.), konkrétne štátu Chu, a zobrazujú mytologické námety. Už na týchto mal'bách vidíme pohyb a život, zachytený jednoduchými tahmi štetca. Z obdobia Západných Han sa zachovali malby a hodvábe a malby na sarkofáku v laku, ktoré sa našli v hrobke v Mawangdui, Changsha. Vidno v nich bohatú predstavivost', zdokonalujúcu sa zobrazovaciu schopnost'. Hanské umenie sa vyznačuje pomerne jednoduchou technikou štetcom, spontánnostou prejavu.

Malba obdobia Šiestich dynastií bola ovplyvnená buddhistic- kými umeleckými postupmi. V tom období sa krajinomalba pomaly osamostatnila od figuralistiky a stala sa osobitým žánrom. Dejiny starej čínskej malby sú okrem iného charakteristické aj pomerne častými zápismi o autoroch, ktorých diela sa nezachovali. Fakt, že poznáme mená čínskych maliarov, má niekol'ko príčin. Jednou je úcta k slovu, vdaka ktorej sa nám zachovalo pomerne vel'ké množstvo literárnych prameňov zo starších dôb. Do určitej doby je to spôsobené aj samotnou podstatou malby, tažším zachovaním, "pominutelnostou“ materiálov, na ktorých boli diela vytvorené. Množstvo literárnych záznamov o obrazoch a maliaroch je dôkazom relatívne vysokého postavenia maliarstva v kultúre starej Číny.

Č́nske historické pramene spomínajú maliara Lu Tanwei 陸探微 (5. storočie), ktorého tvorbu poznáme len zo záznamov výtvarných kritikov. Hovorí sa, že vo svojich malbách používal formu vysoko štylizovanej konceptnej kaligrafie caoshu 草書 a maloval technikou ,jediného tahu“ yibihua 筆畫. Výtvarný kritik a maliar Xie He 謝赫 ho vo svojich $\mathrm{Hu}$ apin 畫品 označil za najlepšieho maliara a zaradil ho do najvyššej prvej triedy. O Lu Tanweiových obrazoch hovoril: 窮理 盡性, 事絕言象, 包前孕后, 古今獨立。Qiongli jin xing, shi jue yan xiang. Bao qian yun hou, gu jin du li. „Vyjadril veci aj pocity dokonale, perfektne zachytil zovňajšok vecí. Nielen že využil skúsenosti svojich predchodcov, ale mal velký vplyv na nasledovníkov. Je jedinečný $\mathrm{v}$ minulosti aj v súčasnosti“ (Zhongguo meishu jianshi 1990, 73).

Iný maliar, spomínaný v čínskych literárnych prameňoch, bol Wei Xie 衛協 (dynastia Jin), ktorý sa venoval malbe postáv. Hoci vel'mi nedbal o formálnu podobnost' xingsi, jeho malby sa vyznačujú spirituálnou konsonanciou qiyun. Gu Kaizhi 顧愷之 (cca 344-405) sa o ňom vyjadril, že dokázal vynikajúco vyjadrit vnútorné pocity zobrazovaného. Wei Xie a jeho diela mali vel'ký vplyv na teórie o qiyun v období Šiestich dynastií (Zhongguo meishu jianshi 1990, 71).

Prvým čínskym maliarom, ktorého malby sa nám zachovali aspoň v sprostredkovanej forme neskorších kópií, bol maliar z obdobia Východných Jin, Gu Kaizhi (cca 344-405). Bol to najvýznamnejší maliar a výtvarný teoretik obdobia Východných Jin. Jeho mal'by kládli dôraz na vyjadrenie povahových vlastností zobrazovaných osôb (Zhongguo meishu jianshi 1990, 71).

Z obdobia Šiestich dynastií pochádza najznámejší výtvarnoteoretický spis od maliara Xie He 謝赫 (5. storočie), ktorý neskôr hlboko ovplyvnil čínsku malbu. Xie He sa zmienil o spirituálnej konsonancii, qiyun 氣韻, termíne, ktorý mal pre neskoršiu čínsku malbu obrovský význam.

\subsection{Rozvoj spontánnej malby za dynastií Sui (581-618) a Tang (618-907)}

V období dynastií Sui a Tang, došlo k rozvoju všetkých maliarskych žánrov. Od dynastie Tang sa datujú začiatky krajinomal'by, ktorá sa neskôr na niekol'ko storočí stala jedným z najdôležitejších žánrov čínskeho maliarstva. Velký pokrok zaznamenala figuralistika. Pravdepodobne pod vplyvom bud- 
dhistického učenia sa obrátila pozornost’ maliarov na žáner mal'by kvetov, ktorý sa do Č́ny pravdepodobne dostal z Indie a ktorý hral neskôr v čínskom výtvarnom umení velmi dôležitú úlohu.

Buddhizmus bol vôbec prvé cudzie učenie, ktoré do Číny masovo preniklo. Kým na severe bolo jeho prenikanie rýchlejšie a priamočiarejšie (v krajinách ovládnutými dynastiou Severných Wei, bol prijatý za štátne náboženstvo), na juhu sa stal vo svojich počiatkoch spolu s taoistickými prúdmi, záležitostou kultúrnej špičky, intelektuálnych kruhov. V interakcii s domácim taoizmom vytvoril viacero rozličných filozofických smerov a prúdov, z ktorých najznámejší je chan 禪 (zen) buddhizmus, ktorý sa vykryštalizoval asi v piatom až šiestom storočí. Buddhizmus v období Šiestich dynastií, za dynastie Tang a neskôr výrazne ovplyvnil čínske výtvarné umenie. Od obdobia dynastie Song sa mnohé osobitné počiny maliarov spájajú práve s chan (zen) buddhizmom 禪佛教.

Maliarstvo dynastie Tang sa rozvíjalo vo všetkých smeroch na základoch dynastie Sui. Velký rozkvet zaznamenala figuralistika a malba koní. Popri zelenomodrej krajinomalbe sa rozvíjala monochromatická krajinomalba tušom. V tom období sa malba kvetov a vtákov a zvierat definovali ako samostatné žánry, ktoré pritiahli pozornost'. Na začiatku dynastie Tang sa prudko rozvíjala figuralistika, reprezentovaná Yan Libenom 閻立本 (cca 601-673), ktorý zjednodušenými tahmi dokázal v skratke vyjadrit podstatné črty osôb. Významné obdobie maliarstva, v ktorom sa objavilo množstvo rozličných štýlov a výrazných osobností, nastalo v strede dynastie. Portréty a buddhistická mal'ba, reprezentovaná Wu Daozim 吳道子 (cca 680-759) a Zhang Xuanom 張萱 (713-755), bola typická vykreslením povahy a zmyslom pre detail. Krajinomal'ba, ktorej predstavitelia boli maliari ako Li Zhaodao 李昭道 (653-718), Wu Daozi, Zhang Zao 張璪 (?-1093), Wang Wei, získala v tom období nezávislé postavenie. V tej dobe sa začala používat maliarska technika pomo 破墨, malovanie do ešte nezaschnutého, vlhkého povrchu, ktorú pripisovali Wang Weiovi. Koncom dynastie to boli malby dvorných dám, reprezentované Zhou Fangom 周昉 (713-741). Na sklonku dynastie si zasluhuje pozornost’ predovšetkým experimentovanie s tušom, a s tým súvisiaca premena v krajinomal'be, pod ktorú sa podpísali Wang Mo 王墨 (?-805) a iní umelci, $\mathrm{v}$ dielach ktorých nachádzame začiatky rýchlo načrtnutej, nespútanej splašovej malby pomo 潑墨, čo znamená „vrhanie tušu“ (volne podla: Yang Renkai 1991, 73-75).

Stopy rýchlej spontánnej malby načrtnutým spôsobom nachádzame v čínskej malbe už viac ako 1000 rokov. Začiatok sa datuje do dynastie Tang a je spojený s menami takých významných maliarov, ako sú Wu Daozi, Wang Wei a inými. „Rýchlost' a pomalost' boli vtedy pokladané za alternatívy viac menej rovnakého významu. Vel'ký maliar mohol pracovat' ktorýmkolvek. Ale v neskorších storočiach preferencie kritikov smerovali viac a viac k ideálu rýchlosti, spontánnosti, pre ktorú bol božským predstavitelom Wu Daozi. Kurzívny, alebo zjednodušený štýl používania štetca sa zrodil v kaligrafii ovela skôr ako ho začali používat' alebo systematicky používat' v malbe“ (Cahill 1988, 74).
Jedným z mimoriadne významných maliarov dynastie Tang bol Wu Daozi, nazývaný aj Wu Daoxuan 吳道玄 (nar. cca 700). Tento vynikajúci maliar sa učil kaligrafiu od slávneho kaligrafa Zhang Xu 张旭 (cca 658-747). Jeho figurálne fresky boli preslávené svojimi nádhernými líniami plnými života. Bol označovaný za „svätca maliarstva“, božského maliara, huasheng 畫聖. Jeho línie sa vyznačovali výrazným rytmom, tempom, hovorilo sa o ňom, že rúcha jeho postáv vyzerajú, akoby viali vo vetre (Jianming meishu cidian 1991, 90). Hoci Wu Daozi bol známy predovšetkým ako figuralista, Zhu Jingxuan 朱景玄 (841-846) v Tangchao minghua lu 唐朝名畫 錄 spomínal aj historku, pravdepodobne apokryfickú, kde uvádzal jeho kvality ako maliara krajiny. Ked' sa Wu vrátil z cesty, kam ho poslal cisár zaznamenat krásu krajiny, bez náčrtkov, s tým, že má obraz zaznamenaný v mysli. Za jediný deň vytvoril nádhernú mal'bu, ktorá zachytila krajinu (Cahill 1988, 72). Za svojho života vraj vytvoril okolo 300 nástenných malieb v chrámoch v Luoyangu a Chang’ane. Nič z jeho diel sa nezachovalo; skutočne, v 11. storočí mohol Su Shi povedat', že videl iba dve z jeho malieb, jeho priatel' Mi Fei 米䒾 (1051-1107) ich videl tri alebo štyri (Sullivan 1977, 133-134, skrátené).

Ideál spontánnosti a rýchlosti mal svoje korene v kaligrafii, predovšetkým v už spomínanej rýchlopisnej kurzíve caoshu. Sám Wu Daozi, ktorého neskorší výtvarní kritici zaradili do najvyššej triedy spomedzi všetkých súdobých maliarov, do triedy „božských“ a na ktorého sa neskorší maliari odvolávali ako na svoj vzor pri rýchlej, spontánnej malbe, bol inšpirovaný kaligrafiou svojho učitela Zhang Xu „šialeného kaligrafa“, ktorý vynikal práve v nespútanej, nečitatelnej, bláznivej kuangcao 狂草.

Ďalší významný tangský maliar a básnik, Wang Wei (699761 ?) bol pokladaný za tvorcu štýlu malby do vlhkého podkladu, pomo 破墨. Wang Wei maloval, podobne ako Wu Daozi, figurálne námety, krajiny, fresky. Objavil poéziu v prírode a začal malovat zimné krajiny, strhujúce symboly pokoja a samoty. Po smrti bol Wang Wei označený za zakladatela monochromatickej malby tušom, „južnej školy“ (Cohn 1951, 49-50), ako ju ovela neskôr nazval Dong Qichang, mingský maliar a výtvarný kritik. Na rozvíjajúcu sa monochromatickú nadviazali songskí a neskôr aj mingskí a qingskí maliari-literáti. V poslednom storočí dynastie Tang, ked’ sa centrum kultúry prestahovalo na juh krajiny, maliari v oblastiach Nankingu a Hangzhou experimentovali s krajinomal'bami vytvorenými polievaním a striekaním na papier, podobným technikám New-Yorkskej školy v roku 1950. Hoci práce týchto expresionistov sa nezachovali, ich štýl bol prebratý niektorými zenovými maliarmi v desiatom storočí a znova v neskoršej dynastii Song (Sullivan 1977, 142).

Vo vychutnávaní slobody boli tangskí maliari, neskôr zarad’ovaní do zvláštnej kategórie yipin 逸品, teda rebelantskí a agresívne experimentálni. Zatial' čo Wang Mo v Zhu Jingxuanovom opise vyzeral, akoby vybuchoval s vínom a tušom, Li Lingsheng a Sun Wei sa javili možno menej divokí, boli však stále bezočiví a prudko nespútaní (Nelson 1983, 416).

Wang Qia 王洽, nazývaný aj Wang Mo 王墨, čo v preklade 
znamená Tušový Wang (?-804) bol tanský maliar, mal’oval borovice, kamene, bol vel'korysej povahy, rád pil alkohol. Traduje sa, že pred mal'ovaním sa opil a ked' bol opitý, „vrhal tušc pomo na hodváb, pričom si pomáhal rukami aj nohami. Na základe premien tušu, jeho hustoty či riedkosti, potom domaloval hory, vodu, oblaky, tak, že to vyzeralo vel'mi prirodzene. Bol vraj prvý, kto začal používat techniku pomo (Zhongguo meishu cidian 1991, 27). V súčasnosti existuje okrem pomo podobný spôsob malby, ale s využitím farieb, nazývaný „vrhanie farieb“ pocai 潑彩, ktorý využíval aj významný čínsky umelec 20. storočia, Zhang Daqian 張大千.

Zou Yigui 鄒 - 桂(1686-1772) svojom texte Xiao shan huapu 小山畫譜 opísal proces, v ktorom Wang Qia tvoril svoje diela: 以墨潑紙素, 或吟或嘯, 腳蹴手抹, 隨其形狀, 為山石 雲水。Yi mo po zhi su, huo yin huo xiao, jiao cu shou mo, sui qi xingzhuang, wei shan shi yun shui (Yang Renkai 1991, 565). Vylial tuš na papier alebo na hodváb, mrmlal si alebo kričal, nohami šúchal, rukami utieral, podla tvaru roztečeného tušu namal'oval hory, oblaky a vodu.

Iný spomedzi slávnych neskoro tangských excentrikov, Zhang Zao 張璪 (aktívny cca 766-778), používal prsty na malovanie obrazov. Neskôr sa hovorilo, že bol prvý, ktorý začal používat' túto techniku. Často používal ošklbaný štetec, maloval podla svojej mysle, vel'koryso tvoril obrovskými gestami. Bol rovnako známy ako Wang Wei (Jianming meishu cidian 1991, 93). Ani z jeho tvorby sa nič nezachovalo.

Zachovali sa iba záznamy ludí, ktorí videli maliara Zhang Zao pri tvorbe. Vraveli, že pred tým, ako začal mal'ovat, 箕坐鼓 氣, 神機始發ji zuo gu qi, shen ji shi fa (Ge Lu 1983, 63).

Sadol sa a ked' nazhromaždil energiu, jeho esprit, inšpirácia začala prúdit'.

Ked' začal malovat', tak: 若流電激空, 驚飆戻天, 豪飛墨噴 ... ruo liu dian ji kong, jing biao li tian, hao fei mo pen (Ge Lu 1983, 63). Štetec tancoval a lietal v povetrí, tuš striekal všade navôkol, podobal sa zábleskom blesku vo vzduchu, jeho pohyby pripomínali veternú smršt na brutálne pôsobiacej oblohe. Zhang Zao maloval stromy a krajinomalbu. Výtvarný kritik Zhang Yanyuan 張彥遠 (815-907) sa o ňom vyjadril v Lidai minghua ji, že: 或以手摸絹素 huo yi shou mo juan su (Yang Renkai 1991, 565). Niekedy pri malovaní na hodvábe používal ruky.

Z diel týchto umelcov, ktorí sa vo svojej tvorbe dostali až na pomedzie abstraktnej malby, sa nezachovalo vôbec nič. Možno aj preto, išlo o štýl malby, ktorý v neskoršej dobe nestál v centre pozornosti, možno jednoducho aj z toho dôvodu, že kopírovat obrazy vytvorené touto technikou bolo pomerne tažké.

Podstatný rozdiel medzi neskoro tangskými excentrikmi a modernými akčnými maliarmi je ten, že kým tí neskorší nechali svoje gestá a splaše ako svoje konečné vyhlásenie, ich čínski predchodcovia tisícročie predtým niekolkými dotykmi štetcom tu a tam zmenili obrazy na krajinomalby. Ale akčná malba a zen nepatria do určitej doby. Sú momentmi v čase a priestore ktoré nie sú spojené žiadnym druhom historickej kontinuity. Jednoducho sa objavujú a znovu objavujú vo večnej súčasnosti (Sullivan 1973, 253).

\subsection{Obdobie Piatich dynastií (907-960) a dynastie Song (960-1279)}

V desiatom storočí došlo v Číne k vel'kému rozkvetu krajinomalby, ktorá sa ako umelecký smer začala rozvíjat už za dynastie Tang. Krajina sa stala viac ako len zobrazením určitého konkrétneho miesta. Pät dynastií je pre krajinomalbu pomerne významnou epochou. Čína bola, podobne ako za obdobia Šiestich dynastií, rozdelená na viacero štátov. Na juhu sa v rýchlom časovom slede striedali krátkodobé dynastie. V tomto z politického hladiska velmi nestabilnom období, nastal velký rozkvet v kultúre a umení. Práve vtedy sa objavil severný štýl, počnúc maliarom krajiny a výtvarným teoretikom Jing Haom 荆浩 a južný štýl, zakladatelom ktorého bol Dong Yuan 董源. Mnohí maliari, ako bol napríklad Dong Yuan, a jeho žiak Juran 巨然, presadzovali štýl nanášania tušových valérov do nezaschnutej mal'by pomo a upúštali od obrysovej línie. V náboženskej mal'be figúr sa objavila štylizácia postáv a štýl mal'by da xieyi 大寫意, ktorý bol reprezentovaný predovšetkým zen buddhistickými maliarmi, ako sú Guanxiu 貫修 (1177-1249) a Shike 石恪 (10. storočie).

Pre rozvoj krajinomal'by mal velký význam Dong Yuan (?962), maliar žijúci v dynastii Južných (Neskorších) Tang. Pochádzal zo súčasnej provincie Jiangxi. Jeho krajinomalba sa zameriavala predovšetkým na zobrazovanie krajiny typickej pre juh Číny, ktorá pôsobila mäkšie ako severný typ scenérie s mohutnými, neprístupnými horami. Maloval hmly, lahko zvlnené pahorky v protiklade so strmými horami severu. Severosongskí maliari o ňom vravievali, že nadviazal na tradíciu Wang Weia. Nanášal farby, čím sa podobal Li Sixunovi 李思訓(653-718). Songský výtvarný kritik Shen Kuo 沈括 sa o ňom vyjadril: 用筆甚草草, 近視幾不類物象, 遠視則景 物粲然。Yongbi shen cao cao, jin shi ji bu lei wu xiang, yuan shi jingwu can ran (Yang Renkai 1991, 104-105). Ťahy štetcom sú mimoriadne zjednodušené. Pri pohlade zblízka akoby sa ani nepodobal na zobrazený predmet, ale pri pohlade z dial'ky sa objaví nádherná krajina.

Od 10 storočia spôsobil zen buddhizmus, naplnený taoistickými myšlienkami, najhlbšiu zmenu v maliarstve, a práve pod jeho vplyvom sa začala rozvíjat monochromatická tušová mal'ba. Zen buddhizmus učí, že božstvo existuje všade, rovnako v prírode ako aj v človeku. Preto môžeme pochopit', že krajinomalba, a popri nej aj zvieratá a rastliny sa môžu posunút do popredia. Ak je raz akceptované, že všetko na tomto svete je ilúzia, vyzerá rovnako pochopitelné, že maliari sa odvrátili od náhodností bytia, od uprednostňovania farieb, zdôrazňovania detailu, a od tém, ktoré postrádali vnútorný zmysel, aby lepšie preskúmali skutočnú esenciu reality. V krajinomalbe sa priestor a hĺbka stali najdôležitejšími prvkami. Vyzerá to, že Súnjatá, doktrína vel'kej prázdnoty, jedna $\mathrm{z}$ fundamentálnych doktrín zenu, tu našla svoju symbolickú reflexiu. Ked' boli prostriedky redukované na absolútne minimum, ako sa často stávalo, malby vyzerali, že boli namalované pod bleskom inšpirácie $\mathrm{z}$ plenéru. Tento proces mohol zodpovedat' intuícii, inej charakteristickej črte zenu. Prirodzene, takisto množstvo postáv, prevzatých zo sveta 


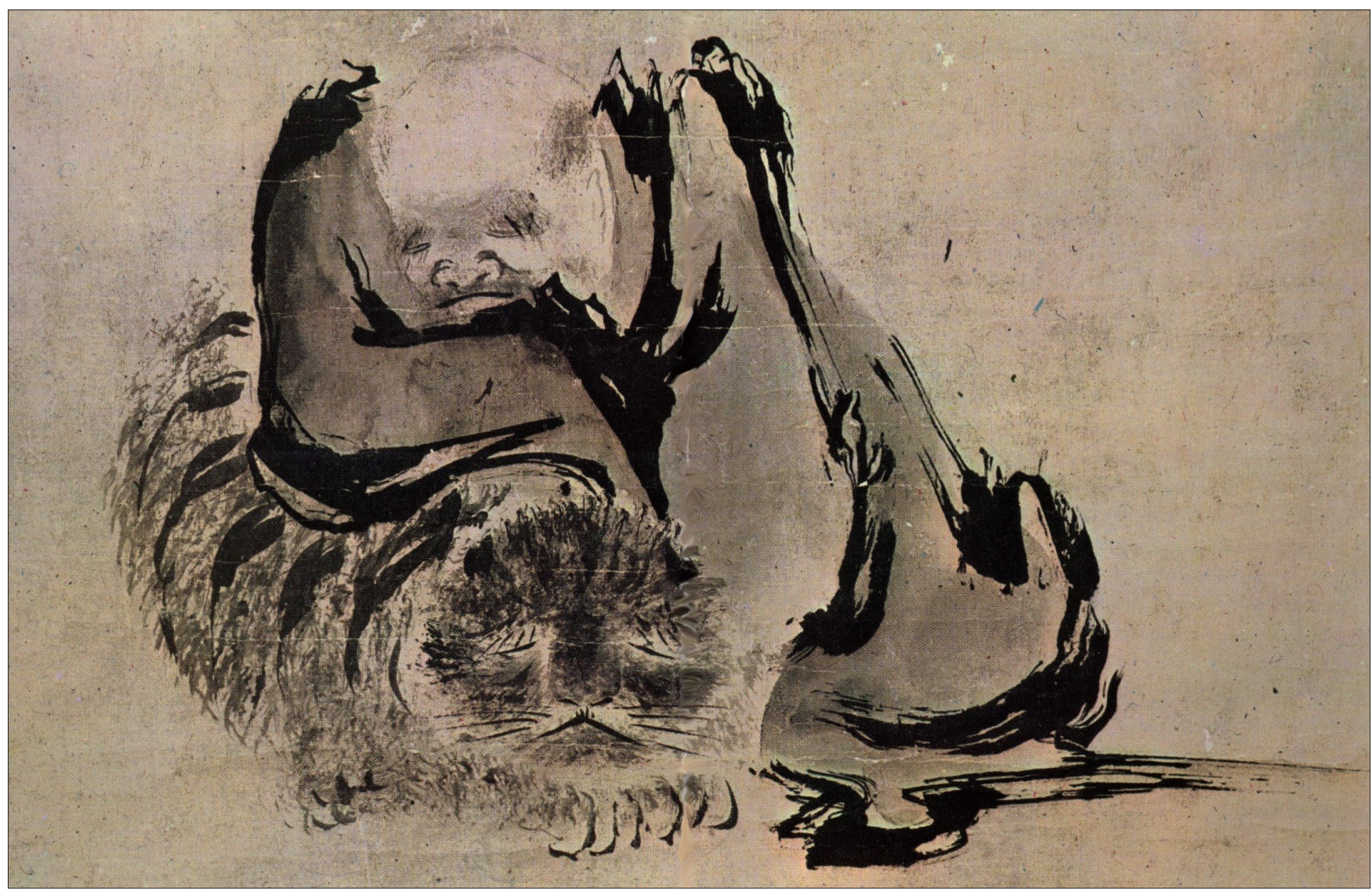

Obr. 1. Dve mysle v harmónii, neznámy autor, v štýle Shike, dynastia Song. Obraz znázorňuje zenového patriarchu opierajúceho sa o leva, čím chce naznačit starú buddhistickú ideu, že pri dosiahnutí určitého stavu mysle, počas meditácie, sa zvieratá stávajú priatelom a nemôžu človeku ubližit.

zenu obohatilo témy a námety songského maliarstva (Cohn 1951, 62-63).

Pokračovatelmi Wu Daoziovej figuralistickej tradície sa v 10 storočí (obdobie Piatich dynastií a Desiatich královstiev) stali maliari z kláštorov meditatívnej sekty chan. Medzi maliarmi vynikali Wu Zongyuan 武宗元 (?-1050), Guan Xiu a Shike. Ich obrazy Buddhových žiakov majú často neskutočné, groteskné črty, gestá a karikatúrne výrazy. Najznámejšia je séria 16 Lohanov od Guan Xiua, ktorá sa zachovala v početných kópiách a frotážach (volne podla: Hájek 2001, 260).

Pri hladaní techniky, ktorou sa dá vyjadrit intenzita a bezprostrednost' a jeho intuície, sa zenový maliar obrátil $\mathrm{k}$ štet$\mathrm{cu}$ a monochromatickému tušu, a s prudkou koncentráciou kaligrafa zaznamenával svoje momenty pravdy vo vonkajších formách Buddhov alebo arhatov, alebo ich naznačoval akýmkolvek subjektom, ktorý sa rozhodol namalovat' (Sullivan 1977, 156).

Jeden zo zenových maliarov z obdobia Piatich dynastií bol Guanxiu (832-912), zenový mních, maliar, ktorý žil v Chengdu. Zachovali sa jeho malby arhatov. Pri malovaní používal techniku, ktorá bola inak bežná pri konceptnej kaligrafii caos$h u$. Okrem toho bol aj vynikajúci kaligraf. Hovorilo sa o ňom, že jeho kaligrafie sa mohli porovnávat so slávnym kaligrafom Huaisuom, ale nevyrovnal sa mu v sláve (Jiangming meishu cidian 1991, 95). Jeho postavy boli vysoko štylizované, ovplyv- nené zenovou filozofiou, novátorské. Jeho arhati boli načrtnutí s typicky zenovou nadsázkou, akoby jediná deformácia mohla byt tou náhlou, elektrizujúcou skúsenostou, ktorú navrhovala zen buddhistická mystika (Sullivan 1977, 157).

Po jeho smrti rozvíjal tento štýl Shi Ke, maliar zo západných Shu, rovnako excentrický a nespútaný, ktorý takisto žil v Chengdu a po páde dynastie Západných Shu sa prestahoval do severosongského Kaifengu. Jeho meno je spojené s najstaršími zachovanými čisto tušovými malbami (obr. 1). Ak to bol skutočne on, kto maloval obrazy mníchov, ponorených do meditácií (Lochanov alebo zenových patriarchov) s takou slobodou štetca, musel byt skutočne revolučný. Jeho tahy štetca sú inštinktívne s expresiou a kaligrafickou dynamikou (Cohn 1951, 63). Pretože Shi Keho povaha bola nespútaná, jeho malby boli 出於繩檢之外 chu yu sheng jian zhi wai „(...) odpútané od obmedzení a pravidiel“" (Yang Renkai 1991, 101). 惟面部手足用畫法, 衣紋皆粗筆成之 wei mianbu shou zu yong hua fa, yiwen jie cubi chengzhi (Yang Renkai 1991, 101): „Maloval tváre, ruky a chodidlá, záhyby odevu naznačoval mohutnými tahmi štetca. "Vytvoril štýl figurálnej malby velkorysým štýlom da xieyi, zjednodušil tahy štetca, rozvinul a objavil nové výrazové prostriedky a efekty tušovej malby. Jeho štýl je mimoriadne osobitý. Mal obrovský vplyv na juhosongského Liang Kai 梁楷 a neskorších figuralistov malujúcich zjednodušenými tahmi štetca (Yang Renkai 1991, 101). 


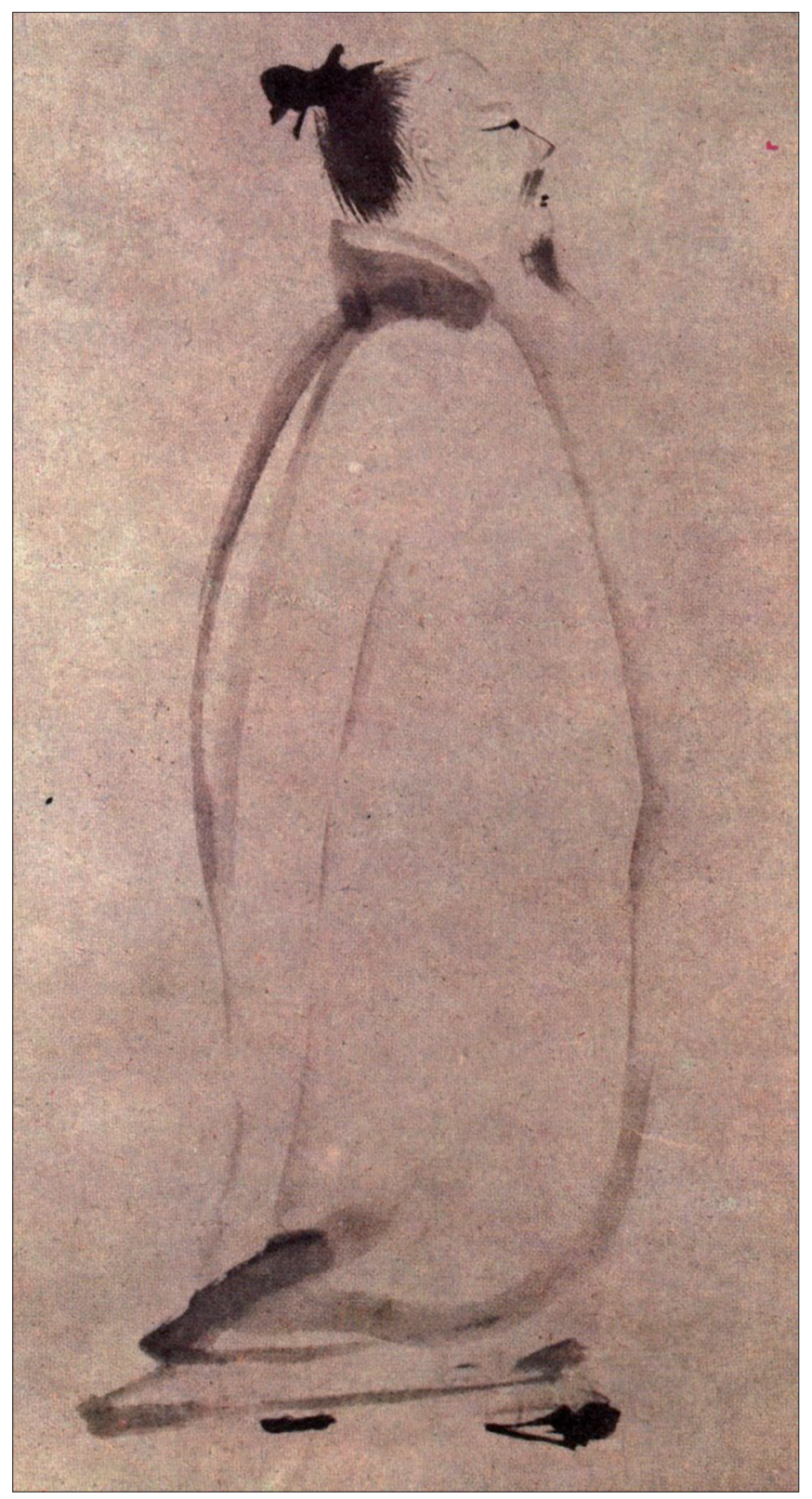

Obr. 2. Liang Kai, Li Bo, kráčajúci a recitujúci báseň (detail postavy, bez hornej časti zvitku), dynastia Song. Li Bo bol slávny básnik z obdobia dynastie Tang, bol známy svojím taoistickým pohladom na svet a svojou vášňou pre víno.

Výtvarný kritik Zhu Jingxuan, žijúci v období Piatich dynastií, vo svojom diela Tang chao ming hua lu zatriedil maliarov do kategórií: neng 能 schopný, miao 妙 zručný, shen 神 božský. Ale pre Shi Ke bolo aj shen málo, pretože títo maliari ešte stále podliehali pravidlám. Preto jemu podobných maliarov označovali ako yipin 逸品, čo znamená „vymykajúci sa pravidlám“ (Sullivan 1977, 157). V jeho vysoko štylizovaných obrazoch sa mal'ba opät posunula na hranice abstrakcie.

Dynastia Song znamenala novú etapu v histórii čínskeho maliarstva. Za dynastie Song dochádzalo k dvom odlišným tendenciám v malovaní. Na jednej strane to bol realizmus v takej podobe, $\mathrm{v}$ akej sa $\mathrm{v}$ ćínskej mal'be nikdy predtým a ani nikdy potom neprejavil v takej výraznej miere, prezentovaný nap- ríklad Zhang Zeduanovým 張擇端 (1085-1145) zvitkom Život pri rieke za sviatkov Čistoty a jasu, kde je venovaná vel'ká pozornost' presnému zobrazeniu života. Tento realizmus mohol pramenit z filozofie neokonfucianizmu. Na druhej strane, práve kultúrna atmosféra za Song dovolila vzniknút hlboko subjektívnej monochromatickej malbe literátov, ktorí sa bránili preniknút príliš hlboko do sveta prírody a materiálnych vecí. Z tohto obdobia sa nám zachovali diela od mnohých maliarov, ktoré sú už originály, nie neskoršie kópie.

Zatial' čo songskí profesionálni a palácoví maliari často sa snažili o presnú, precíznu mal'bu, zdôrazňovali realistické spodobenie, kým maliari-literáti pokladali za prvoradé zachytenie ideí xieyi, zapísat' v obrazoch svoje pocity a emócie, vel'korysé tahy štetca, nenechat sa spútat' obmedzeniami pravidiel mal'by (Zhongguo meishu jianshi 1990, 128).

Na začiatku dynastie Severných Song sa malba rozvíjala v cisárskej Hanlinskej akadémii. Táto akadémia mala $\mathrm{v}$ tej dobe pokrokový účinok. V severosongskej akademickej malbe najviac vynikala krajinomalba. Medzi jej slávnych predstavitel'ov patria Li Cheng 李成 (919-967), Fan Kuan 范寬 (11. storočie), Guan Tong 關全 (907-960). Ďalší velmi výrazný maliar krajiny je Guo Xi 郭熙 (11. storočie). Za dynastie Song sa termín prenos ideí, chuanshen, ktorý sa predtým používal iba vo figuralistike, rozšíril do krajinomal'by a mal'by kvetov a vtákov.

Guo Xi bol významným maliarom, patriacim do cisárskej maliarskej akadémie. Inšpiroval sa tvorbou Li Chenga, no jeho krajinomalba je ešte prirodzenejšia, precíznejšia, vyjadrujúca jemné premeny prírody. Okrem zobrazenia krajiny pridal výrazné citové zafarbenie obrazov. Hoci patril k profesionálnym maliarom, jeho dielo obdivovali aj vtedajší maliari-literáti. Okrem toho bol aj výtvarným teoretikom, ktorý diskutoval predovšetkým otázky týkajúce sa krajinomalby (Yang Renkai 1991, 170).

Koncom dynastie Severných Song malý krúžok intelektuálov, zoskupení okolo vel'kého básnika Su Shi, nazývaný aj Su Dongpo 蘇東坡 (1036-1101), jeho učitel’ v mal'ovaní bambusu, Wen Tong 文同, maliar Mi Fei, učenec a kaligraf Huang Tingjian 黃庭堅 (1045-1105) a iní, prišli s revolučnou ideou, že účelom malovania nie je zobrazovanie ale expresia. Podla nich, ciel'om maliara krajiny nie je evokovat divákovi rovnaký druh pocitov, aký by mohol mat' keby hladel na samotné hory, ale odhalit’ svojim priatelom niečo zo svojich myšlienok a pocitov. Hovorili o požičiavaní si foriem kameňov, stromov alebo bambusu, $\mathrm{v}$ ktorých $\mathrm{v}$ tom momente nachádzali prístrešie pre svoje myšlienky a pocity. Ich práca štetcom bola osobná a odrážajúca ich charakter rovnako ako ich písmo (Sullivan 1977, 168). Snažili sa o tvorbu pod vplyvom náhlej inšpirácie, neobmedzovali sa opisovaním vonkajšieho tvaru objektov. Ich vkusu vyhovovalo vyjadrovanie sa $\mathrm{v}$ monochromatickej malbe (Yang Renkai 1991, 157).

Songskí maliari-literáti urobili d’alší krok k tomu, aby sa kultúrna úroveň umelca stala dôležitou súčastou obrazu. Vel'ké množstvo ich diel bolo výrazom autorovho citu. V ich dielach a úvahách dominuje snaha o vyjadrenie subjektívnych pocitov a atmosféry, protest proti prehnanému kopírovaniu reality 
a prehnanému zobrazovaniu tvarovej podobnosti xingsi, tým prúd songskej wenren hua ovplyvnil mal'bu literátov až so súčasnosti (Zhongguo meishu jianshi 1990, 123).

Maliari-literáti si vysoko vážili morálku v spojení s malbou, tým sa vnútorný obsah zvýšil o autorov subjektívny názor, zahŕňala maliarove vedomosti, morálku, a iné faktory. Objektívna realita môže sa priblížit tvorivej podstate umeleckej tvorby iba po maliarovom subjektívnom pretvorení na určitej významovej rovine. Ak má človek vysoký charakter, „spirit-consonance“ qi yun 氣韻 $\mathrm{v}$ jeho obrazoch nemôže byt nízke. Preto sa požaduje vysoká morálka autora, vedomosti a vytríbený umelecký vkus, ktorý sa v čínskom tvorivom maliarskom procese sa vyjadruje ako norma, skutočné pocity a úprimné emócie, aby mohol dostat' umelecký efekt, že ked' človek uvidí obraz, akoby videl tvorcu samotného (Deng Fuxing 1986, 19). Su Shiho priatel' Wen Tong (1018-1079) sa preslávil v maliarstve predovšetkým svojimi bambusmi malovanými priamo štetcom namočeným do tušu, bez obrysových línií (čierne bambusy). Wen Tong často prirovnával tušový bambus $\mathrm{k}$ „tušovému ušlachtilému mužovi“ mo jun 墨君. Hovoril o sebe, že miluje bambusy a maluje ich, pretože tak vyjadruje svoju osobnost' a morálku. Zdôrazňoval, že „idea predchádza štetcu“ a esprit mal'by leží mimo pravidiel a techniky. Veril, že pri malovaní bambusu musí človek mat najprv bambus vyrastený vo svojej hrudi (Yang Renkai 1991, 189-190).

Ďalší z kruhu maliarov-literátov, básnik, literát, maliar a kaligraf, Mi Fei, alebo Mi Fu (1051-1107), nekopíroval a vo svojej tvorbe nebol obmedzený predošlými maliarmi. Jeho technika bodov mi bodov bola skutočne progresívna. V malbách nezdôrazňoval vonkajšiu podobnost', veril, že v krajinomalbe 古 今相識師, 少有出塵格 gu jin xiang shi, shao you chu chen ge (Zhongguo meishu jianshi, 1990, 136) ... starí majstri sú braní za učitelov, súčasní maliari sa učia od nich, velmi málo z nich prekročí pravidlá, vzory.

Pri mal'ovaní sa nesnažil o precíznost' a techniku. „Mi Fei bol niekým, kto mal slabost' pre starých excentrikov. Bol obdivovatel' maliara z jedenásteho storočia, Sun Zhiwei. Vravelo sa o ňom, že v snahe zbavit svoje diela profesionálnej práce príležitostne používal iné nástroje ako štetec na malovanie, teda metódy, ktoré boli prvýkrát vyskúšané tangskými umelcami, ktorých výtvarní teoretici zarad’ovali do triedy yipin. Vo svojom používaní velkých vlhkých bodov a zrieknutí sa jemných vonkajších línií, preto bol často pokladaný za dediča techniky pomo umelcov ako bol Wang Mo. Jeho štýl, alebo jeho neskorší stereotyp, vyjadroval niečo agresívne alebo impulzívne $\mathrm{z}$ atmosféry pretrvávajúcej od Tang" (Nelson, 1983, 416-417). Mi Feiov syn Mi Youren 米友人 (1074-1153) pri malovaní krajiny tiež „pridávaním bodov vytváral dym a oblaky, nedbalé, jednoduché a pritom dokončené" (dian di yan yun, cao cao er cheng 點滴煙雲, 草草而成), sám nazýval tento spôsob mal'by „tušové hry“ moxi 墨戲, nesnažil sa pritom o vonkajšiu podobu, usiloval sa o prirodzenost'. Vyjadril estetické názory a pocity, atmosféru songských maliarov-literátov (wenren) a úradníkov (Zhongguo meishu jianshi, 1990, 136).

Obaja maliari, Mi Fei a Mi Youren, používali jednoduché, zjednodušené tušové málo farebné línie a body, ktorými vy-

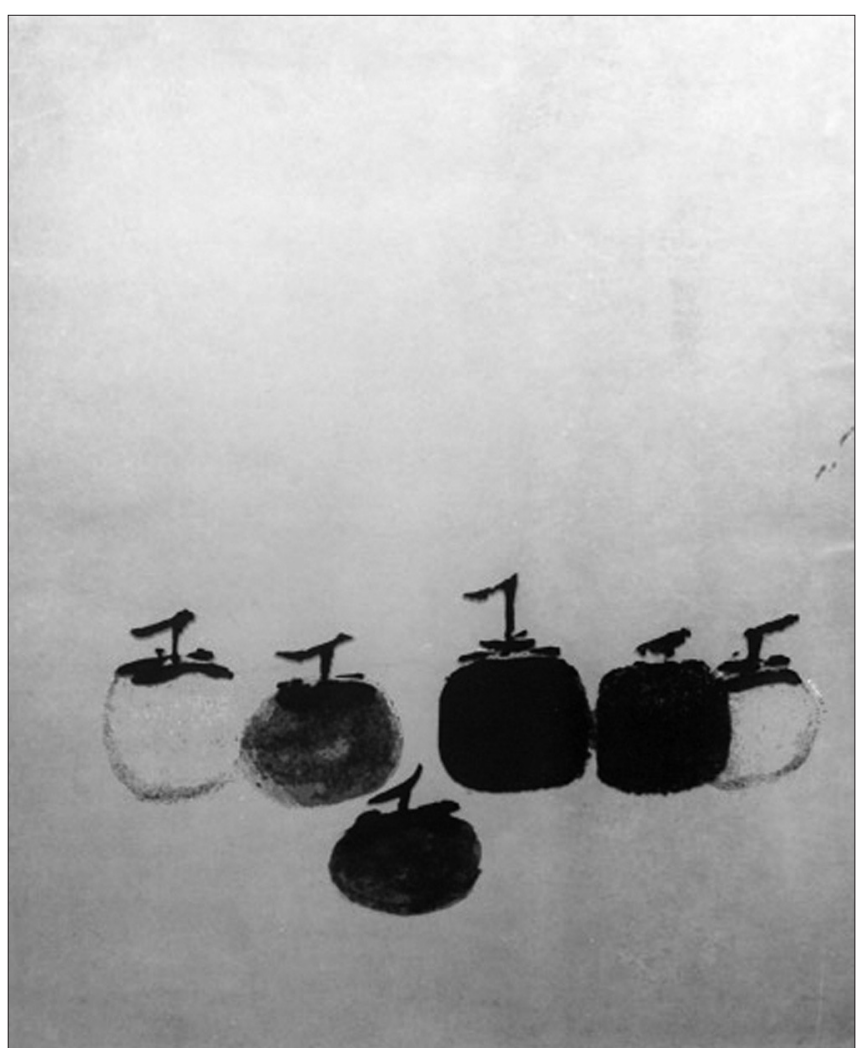

Obr. 3. Mu Xi, Šest' tomelov, dynastia Song. Táto malba tušom je vo svojej jednoduchosti považovaná za ikonu zenu.

jadrovali krajinomalbu, oblaky, dym. Hovorilo sa, že krajinomalba 至兩米畫法大變, 蓋意過於形 Zhi liang mi, er hua fa da bian, gai yi guo yu xing (Zhongguo meishu jianshi 1990, 136) ... v období oboch Mi zaznamenala malba vel'ké premeny, idea presiahla vonkajšiu podobnost'. Tento štýl mal'by mal vplyv nielen na technickú stránku malby tušom, ale začal aj novú tvár malby literátov, wenren hua (Zhongguo meishu jianshi, 1990, 136).

Ich maximálne štylizované, nejasné, akoby do hmly ponorené hory, vytvorené technikou, ktorá bola neskôr nazvaná podla nich, mi-body (mi dian), sú semiabstraktné. Už nejde o konkrétne miesto, je to krajina snov, nezávislá od objektívnej reality.

Ďalší výrazný predstavitel' wenren hua, básnik a maliar Li Gonglin 李公麟 (1049-1106), vynikal vo vyjadrovaní pocitov a emócii maliara. Ked' maloval bohyňu Guanyin, tvoril svoju subjektívnu, osobnú Guanyin 觀音, chcel vyjadrit' jej pocity. Ako sám povedal: 自在在心不在相。Zi zai zai xin bu zai xiang. (Zhongguo meishu jianshi, 1990, 127). Slobodné vyjadrenie je v srdci, nie vo vonkajšku. Používal spôsob malby baimiao 白描, techniku, ktorá nepoužívala farby, tvar objektu bol zachytený výlučne prostredníctvom tušových línií (Zhongguo meishu jianshi, 1990, 127).

Za Južných Song sa maliari malujúci krajinomalbu snažili o zachytenie ideí, yijing, ich cielom bolo vyjadrenie svojich pocitov. Maliari sa už nesnažili o formálnu dokončenost’ obrazu. Ale práve naopak, zdôrazňovali niektorú jeho čast'. Ich 


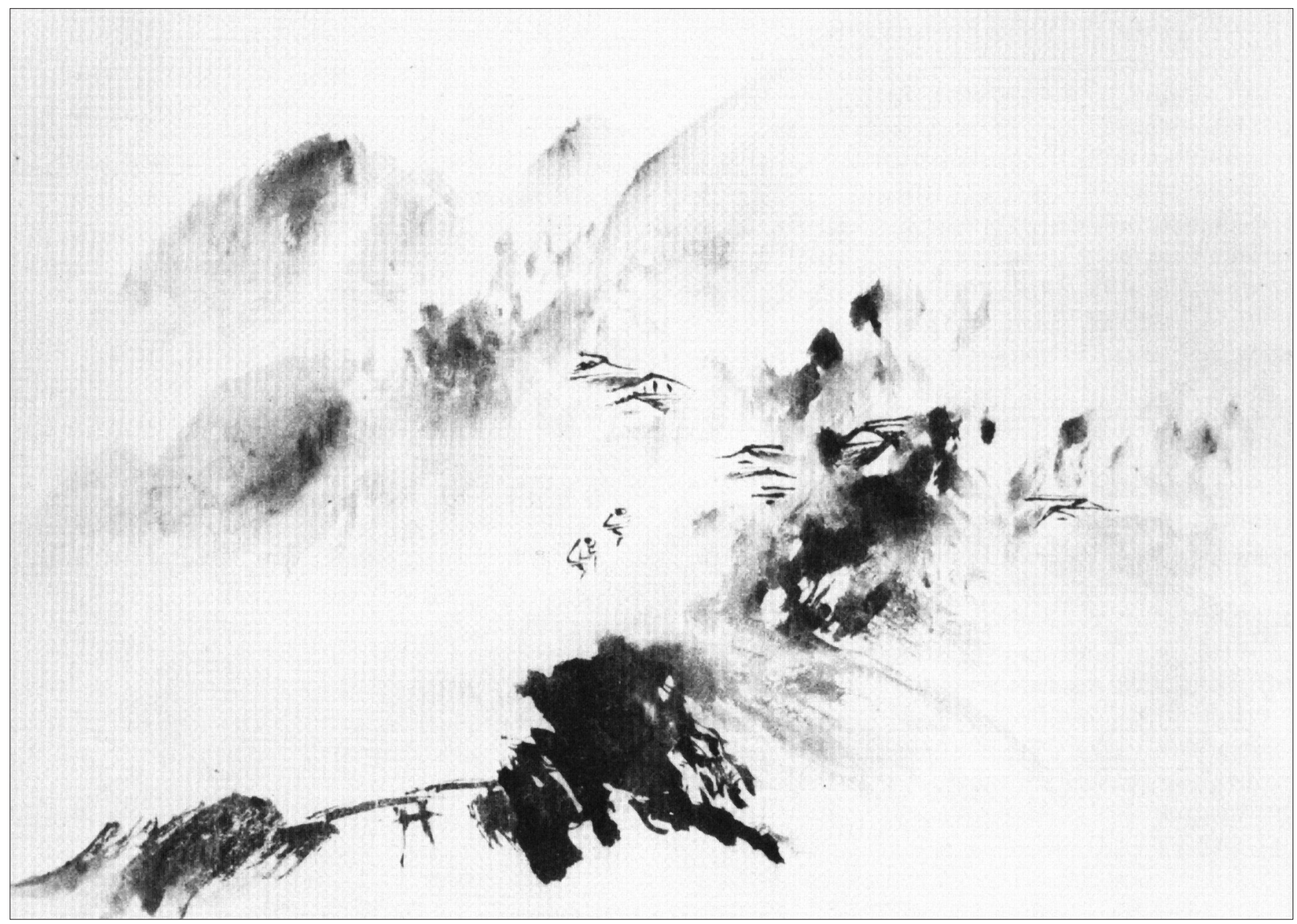

Obr. 4. Ying Yuqian, pripisované, Horská dolina v trhajúcej sa hmle, 13. storočie. Malba tušom, ktorú od abstrakcie delí len niekolko tahov štetcom.

tahy štetcom boli vel'korysejšie, mohutnejšie, menej deskriptívne. Vo väčšej miere využívali výrazové možnosti tušu. Li Tang 李唐 (1050-1130) bol pokladaný za zakladatel’a maliarskeho štýlu Juhosongskej školy. Liu Songnian 劉鬆年 mal vel'ký význam pri vykreslovaní južnej krajiny. Typickí predstavitelia využívania rohovej kompozície boli akademickí maliari Ma Yuan 馬遠(1190-1279) a Xia Gui 夏圭 (dyn. Song). Ich vel'korysé zdôrazňovanie jedného kútu malby, alebo určitého prvku krajiny, ktoré na malbe zanechávalo vel'kú prázdnu plochu, zjednodušovalo kompozíciu a scenériu, zvýrazňovalo hlavný prvok na obraze. Práve tým sa scenéria stávala dokonalou, nepôsobila nedokončeným dojmom. To je nový tvorivý prínos Ma Yuana a Xia Guia do krajinomalby (volne podla: Yang Renkai, 1991, 160).

Možno vd’aka zjavnej vizuálnej a emocionálnej výzve sú diela školy Ma-Xia, ako ich nazývajú, v západných očiach reprezentantom samotnou podstatou ćínskej krajinomalby a mali hlboký vplyv aj na japonskú krajinomal'bu. Ich vyjadrovací jazyk nie je celkom nový ale v umení Ma Yuana a Xia Guia sa rôzne tahy objavili naraz, spojené so suverénnym majstrovstvom štetca, ktoré by hraničilo s manierizmom, keby nebolo tak hlboko predchnuté poéziou (volne podla: Sullivan 1977, 175-176).
Za dynastie Song došlo $\mathrm{k}$ d’alšiemu rozvoju buddhistického maliarstva. Pre výtvarné umenie bola najdôležitejšia jeho škola zen, ktorá svojím antidogmatizmom otvorila cestu k umeleckému vyjadrovaniu. Ak Buddha mohol byt' vo všetkom, všetko mohlo nadobúdat' vyšší, transcedentálny význam, čo dokazujú malby zenových maliarov tej doby.

Známy juhosongský maliar Liang Kai bol v rokoch 1201-1204 úradníkom, potom sa utiahol do ústrania a stal sa zenovým mníchom „vzal so sebou techniku štetca a la Xia Gui“" (Sullivan, 1977, 178). Mal rád alkohol, cisár mu daroval zlatý opasok, on ho zavesil v záhrade a odišiel. Maloval figuralistiku, kvety a vtáky, krajinu, všetko vel'mi dobre. Vynikal v mal'ovaní obrazov, pri ktorých používal vel’mi málo línií, zjednodušujúcich. Bol zakladatelom prvým maliarom ktorý spôsobil neskoršie figurálnu mal'bu v štýle xieyi za dynastií Yuan, Ming a Qing (Zhongguo meishu jianshi, 1990, 128). O jeho obrazoch je záznam vo Vzácnej knihe o malovaní (Tu hui bao jian 圖繪 寶鑒). 精妙之筆。… 皆草草, 謂之減筆 jing miao zhi bi ... Jie cao cao, wei zhi jian bi (Yang Renkai 1991, 207). „Vynikajúce tahy štetcom, mimoriadne zjednodušené, nazývajú ich niekolko tahov." Jeho diela je možné rozdelit na skoré a neskoré. Jeho poňatie drapérií a detailné vykreslenie hláv v niektorých jeho obrazoch nám pripomína Wu Daozi, to môžu 
byt jeho skoršie práce. No aj tu je nepochybná osobitost jeho štýlu a originalita inšpirácie. Neskôr sa jeho metóda očividne zmenila na metaforu a využívajúc divoké a vehementné tahy štetca zametal nad podlahou s kaligrafickým rytmom. Do tejto fázy patria dve zobrazenia Šiestich patriarchov zenovej sekty a jeho portrét Li Boa 李白. Bola niekedy duchovná postava básnika portrétovaná presvedčivejšie a úspešnejšie? Niekolko línií, vibrujúcich a sústredených a tu stojí (Cohn 1951, 73-74). Portrét Li Boa patrí medzi Liang Kaiove diela, ktoré sa svojou stručnostou, úspornostou a velkorysými tahmi štetca dostali vel’mi blízko $\mathrm{k}$ abstraktnému maliarstvu (obr. 2).

Ďalší vynikajúci zenový maliar bol Mu Xi 牧溪 (?-1281), nazývaný aj Fachang 法常. Jeho repertoár bol velmi široký, zahŕňal azda všetko, od početných zobrazení Guanyin, bohyne zlutovania, opice a iné námety. Jeden z jeho najznámejších obrazov predstavuje slávnych Šest tomelov. Maloval aj draky, ktoré sa v zenovom poňatí stávajú symbolom náhleho osvietenia, ako ked'sa drak vynorí z mrakov (Sullivan 1977, 177). Ak sa Liang Kai javí ako pravý dramatik, Mu Xi (Fachang) je senzitívny lyrik. Vieme $s$ istotou, že sa stal zenovým mníchom, pokial ide o Liang Kaia, sú tu určité pochybnosti. Čínske zdroje sa málo zmieňujú o Mu Xi, možno preto, že nebol akademikom. Najvyzretejšie diela spojené s Mu Xiho menom patria medzi najväčšie objavy v čínskom maliarstve (obr. 3). Starší Liang Kai mohol byt jedným z jeho učitelov, ale kým on tažil väčšinou z graficky akcentovaných línií, Mu Xiho tahy štetca sú prevažne rozpíjavej povahy. Jeho osobitný charakter leží v jeho vizionárskej sile, v jemnosti, s akou kládol objekty na povrch obrazu, a v bohatstve tónov jeho tušovej palety (Cohn 1951, 74).

Najodvážnejší krok vo formovaní krajinomalby, ktorý dokonca prekročil Xia Guia, Liang Kaia alebo Mu Xiho, bol spravený iným zenovým mníchom, o ktorom predpokladáme, že žil v tom čase. Štetec Ying Yuqiana (13. storočie) sa vôbec neviazal $\mathrm{k}$ prírodným formám. S očividne náhodne vrhnutými splašmi vyjadril niekol'ko domov, usadených $\mathrm{v}$ horách, most ležiaci cez riečku, človeka stúpajúceho do vrchov. V skutočnosti boli dosiahnuté hranice toho, čo môže byt dosiahnuté čistým jazykom štetca. Malba je zaznamenaná v okamihu a zdá sa, akoby bola dosiahnutá idea zenovej intuície (Cohn 1951, 74). Podla Sullivana, v dielach Ying Yuqiana prežilo niečo z kvalít neskoro tangských excentrikov, ako bol Wang Mo a iní, z ktorých diel sa nezachovalo vôbec nič (Sullivan 1973, 253). Ako vidíme na ilustrácii, jeho malba nesie v sebe výrazný abstraktný náboj (obr. 4). Nebyt jemných tahov, ktorými dokreslil detaily a dodal obrazu charakter krajiny v hmle, bola by to fakticky abstraktná mal'ba.

\subsection{Dynastia Yuan (1271-1368)}

Po páde dynstie Song sa dostala k moci mongloská dynastia Yuan. Napriek tomu, že Mongoli vojensky dobyli Čínu, stalo sa to, čo sa v čínskych dejinách zopakovalo viackrát; vojensky podrobená, no kultúrne vysoko vyspelá Čína ostala sama sebou, dobyvatelia zachovávali staré čínske tradície a často sa asimilovali, do väčšej či menšej miery. Yuanská malba sa sebadefinovala v nadväznosti na tradíciu Tang, Piatich dynastií a Song. Jej výrazným znakom je rozkvet literátskej malby. Pôvodné črty wenren hua sú v jej úzkej spätosti s literatúrou a v dôraze na prácu štetcom a tušom. Yuanská malba si vážila esenciu kaligrafie a dôsledkom toho bolo ešte užšie spájanie poézie, malby a kaligrafie do jediného celku, pričom tvarová podobnost' xingsi stála na podradnom mieste. Vo všeobecnosti možno povedat, že yuanská malba zdôrazňovala subjektívne vyjadrenie emócií v maliarstve a prírodné objekty sa stali prostriedkom na vyjadrenie maliarových názorov, záujmov a emócií. Tým sa stala kontrastom k tomu typu songskej mal'by snažiacemu sa o presné vyjadrenie tvaru. Zjednodušujúce, oslobodené umelecké postupy významných predstavitelov yuanskej malby vyniesli čínsku krajinomalbu na nový vrchol. Yuanská krajinomal'ba si požičiavala tvary predmetov na vyjadrenie osobnosti maliara, jeho povahy. Zjednodušujúci štýl xieyi sa prejavil takisto $\mathrm{v}$ malbe kvetov a vtákov a figurálnej mal'be. Subjektívne črty sa prejavujú ešte intenzívnejšie ako v songskej malbe.

Za dynastie Yuan nastal rozvoj mal'by literátov, ktorí budovali svoju malbu nie na kopírovaní prírody, ale na subjektívnom tvorivom prístupe k realite. Možno povedat', že svojimi mal'bami tvorili novú realitu, inšpirovanú objektívnou skutočnostou, no nezávislou od nej. Po vytvorení dynastie Yuan sa maliari - učenci obrátili dovnútra, v snahe uniknút zo politických a sociálnych otrasov, ked'Čínu ovládli mongolské kočovné kmene. Mal'ba literátov bola $\mathrm{v}$ tom čase ani nie tak expresiou ako individuálnou odpoved’ou a obranou voči nestálosti a premenlivosti života. Za dynastie Yuan v umeleckom oživení vidíme zápas autorov za preorientovanie sa a opätovné objavenie individuálnej identity (Wen C. Fong 1992, 9).

Č́nska malba, chápaná v pôvodnom slova zmysle, zdôrazňuje 妙在似與不似之間 miao zai si yu bu si zhijian (Xue Yongnian 1992, 358), teda „krásu na rozhraní medzi podobaním a nepodobaním sa“. Vyjadrené súčasným jazykom, „podobanie sa“ $s i$, 似 poukazuje na kopírovanie konkrétnych faktorov realistickej skutočnosti, zatial' čo „nepodobanie sa“, busi 不 似, ukazuje, že nie je zviazaná kopírovaním prvkov realistickej skutočnosti. Preto možno povedat, hodnota „krásy na rozhraní medzi podobaním a nepodobaním sa"leží medzi realistickým a abstraktným zobrazovaním. Každý vie, že v procese tvorby čínskej malby je zámerne zdôrazňovaná stránka nepodobnosti busi, čo sa začalo v dielach maliarov-literátov wenren a pomerne rozvité bolo za dynastie Yuan. Yuanskí maliari literáti sa snažili dosiahnut abstraktné prvky nepodobnosti, krátko po období, kedy dôraz na realistické zobrazovanie (ying wu xiang xing 應物象形) za dynastií Severných a Južných Song dosiahol vrcholného bodu. V snahe, aby neopakovali úspechy svojich predchodcov, sa pozornost' maliarov presunula od zobrazovania objektívneho sveta na zobrazovanie subjektívneho sveta, aby vyjadrila obrovské rozdiely medzi ludskými osobnostami a povahami (Xue Yongnian 1992, 358).

Hlavný prínos malby zo začiatku dynastie Yuan je v malbe úradníkov, ktorá prispela $\mathrm{k}$ dalšiemu posunu čínskeho maliarstva ako v teoretickej tak aj tvorivej oblasti. Maliari po- 


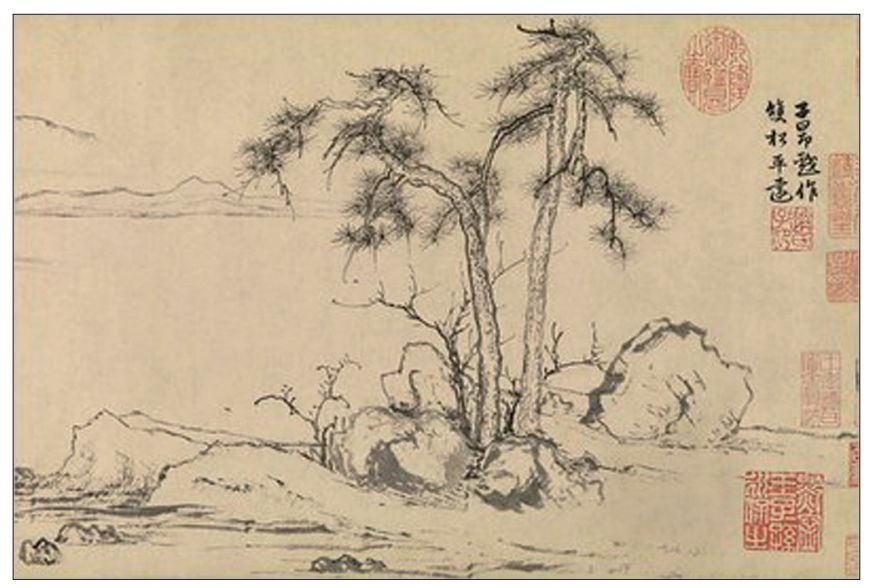

Obr. 5. Zhao Mengfu, Dvojitá borovica, dynastia Yuan.

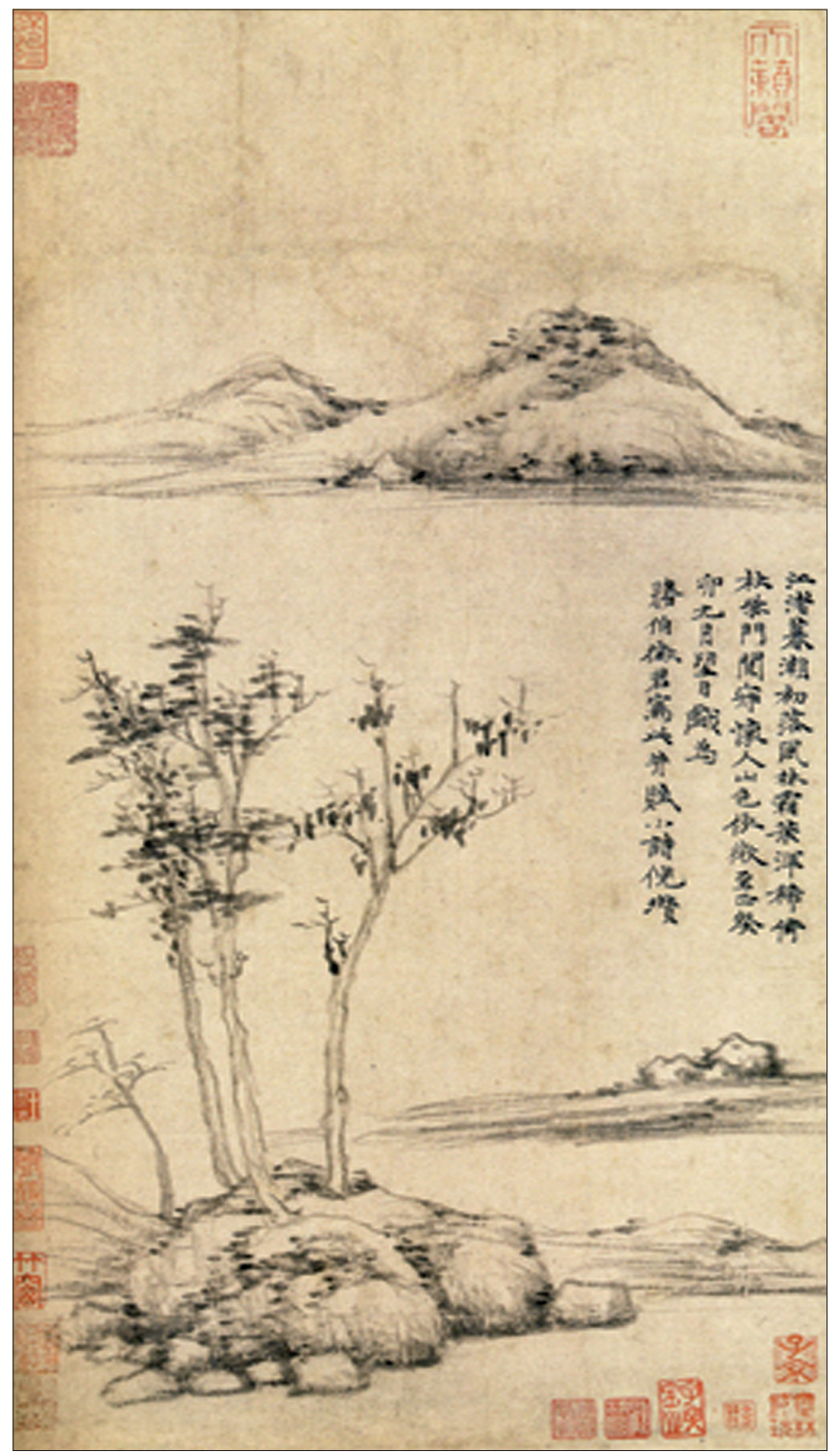

Obr. 6. Ni Zan, Vietor medzi stromami na brehu rieky, datované do roku 1363, cca 59x31 cm. Vidíme tu niekolko stromov a vzdialenú scenériu rieky, bez ludského príbytka. Z obrazu sála pocit osamelosti. užívali štetec a tuš predovšetkým na vyjadrenie osobných ideálov a morálky. Vo svojich dielach vyjadrovali spomienky na minulé dynastie. Najvýznamnejší spomedzi nich bol Zhao Mengfu 趙孟煩 (Zhongguo meishu jianshi, 1990, 149).Zhao Mengfu (1254-1322), nazývaný aj Zi’ang 子昂, pochádzal zo súčasnej provincie Zhejiang. Vychádzal z estetiky a nálady, jeho dielo nadviazalo na malbu Tang a Severných Song. Jeho štýl bol jemný, málo farebný, kultivovaný, jednoduchý (obr. 5). Vystupoval proti songskej akademickej mal'be, ktorá prehnane zdôrazňovala vonkajšiu, tvarovú podobnost'. V mal'be sa usiloval o esprit starobylosti. Zdôrazňoval vztahy malby a kaligrafie, pri malovaní vo vel'kej miere používal kaligrafické tahy, aby tak zdôraznil jej umeleckú expresivitu (Zhongguo meishu jianshi, 1990, 149-150).

Zvrat $\mathrm{v}$ čínskom maliarstve od realistickej reprezentácie k symbolickému sebavyjadrovaniu, ktorý sa odohral v koncom 14. a začiatkom 15. storočia, bol produkt a zároveň nástrojom zmien v čínskej spoločenskej a kultúrnej histórii (Fong 1992, 7). V spoločenskej atmosfére dynastie Yuan a podmienok mysle maliarov-literátov, vonkajšia podobnost' xingsi a realistické zobrazovanie boli dané na vedlajšie nedôležité miesto, viac kládli dôraz na subjektívne pocity, názory, mysel. V čínskej mal'be bolo stále kladený dôraz na základný princíp spiritálnej konsonancie, qiyun shengdong 氣韻生動, no v tom období nebol kladený do reality, ale do subjektívnej a pocitovej sféry. To, čo malo pôvodne vyjadrovat' výzor a ducha vo figuralistike, sa stalo kritériom na vyjadrovanie subjektívneho pocitu, subjektívnej atmosféry krajinomalby (Li Zehou 1982, 180).

Dôraz na prácu štetca a tušu sa stalo špecifikom dynastie Yuan. Bol to nový tvorivý rozvoj v čínskom maliarstve. Malba dynastie Yuan získala tak pomerne osobité estetické výsledky. Ked' pozrieme na mal'bu maliarov-literátov, krása maliarstva neleží iba v opisovaní prírody, ale rovnako, ba ešte viac, záleží na podstate línií malby, farieb a ostatných prirodzených vlastnostiach tušu a štetca. Tuš a štetec sa nemusí opierat’ iba o vyjadrovanie zobrazovaného objektu (krajiny a vecí), má svoju vlastnú nezávislú krásu. Nie je to iba formálna krása, krása kompozície, ale formou kompozície vyjadruje rozličné subjektívne ludské svety. Takto sa tradícia čínskeho umenia línií dostala na najvyšší stupeň, od starých malovaných keramík a bronzov a pečatnej kaligrafie, línie sú stále dôležitým prvkom čínskej estetiky výtvarného umenia. Vo figuralistike sú to napríklad 鐵線描 tie xian miao „obrysové línie akoby vymodelované z drôtu“ alebo吕帶當風 wu dai dangfeng „línie odevov vejúce vo vetre, v štýle Wu Daozi“ a iné, všetky hovoria o kráse línií (Li Zehou, 1982, 181).

$\mathrm{V}$ tom období došlo k úzkemu prepojeniu poézie a malby. Od dynastie Yuan sa začala zdôrazňovat' dôležitost' kaligrafie, čo sa stalo charakteristickou črtou nielen malby literátov, ale čínskej malby vo všeobecnosti. Nemožno ich jednoducho kritizovat pre formalizmus, naopak, vyjadrovali vyspelý estetický názor a estetický ideál. Plynutie a ohýbanie, pôvodná vlastnost' línií, tmavost' a svetlost' tušu, kompozícia, boli tým, čo vyjadrovalo pocity, silu, atmosféru, pocit časopriestoru, tým, čo vytvorilo dôležitú scenériu krásy (Li Zehou, 1982, 181). 
V strede a na konci dynastie Yuan mali obrovskí vplyv na neskoršiu malbu štyria umelci, neskôr nazývaní Štyria velkí majstri dynastie Yuan; Huang Gongwang 黃公望(1279-1368), Wu Zhen 吳鎮(1280-1354), Ni Zan 倪瓚(1301-1374), Wang Meng 王蒙 (cca 1308-1385). V umení boli priamo ovplyvnení Zhao Mengfuovou malbou. Svojimi dielami vyjadrovali ich pocity, dojmy a životný pocit. Ich krajinomalba kladie dôraz na tahy štetca a tuš, záležalo im na osobnom štýle. Vo svojom umení sa snažili 寫胸中逸氣 xie xiong zhong yiqi (Zhongguo meishu jianshi, 1990, 152), zaznamenat vnútornú oslobodenú odpútanú, nespútanú atmosféru.

Vynikajúci maliar, ktorý sa, podobne ako jeho songský predchodca Wen Tong, preslávil malovaním bambusu, Wu Zhen (1280-1354), bol maliar, literát, básnik ako aj výborný kaligraf. Zobrazoval krajinomalbu, slivy a už spomínaný bambus. Ťahy štetca v jeho malbách bambusu sú velmi volné, akoby nedbalé, naplnené hlbokým emocionálnym nábojom (Zhongguo meishu jianshi, 1990, 152). Vo svojich malbách často spájal malbu a kaligrafiu.

Ked' už raz existovala v maliarskej teórii idea, že dobrá mal'ba nemusí zachovávat' vernú podobu svojmu subjektu, niektorý umelec musel skôr či neskôr spravit’ d’alší krok a hrdý na nepodobnost' svojich malieb naznačovat', že sa v nich zaoberá vyššou rovinou ležiacou nad reprezentáciou. Prvým čínskym umelcom, ktorý prijal túto nelogickú, vel'mi modernú pozíciu, sa zdá byt' Ni Zan (Cahill 1976, 166). Jeho dielo má osobitný význam pre neskoršiu malbu aj pre rozvoj subjektívneho faktoru v čínskom maliarstve. Ni Zan (1301-1374) pochádzal z bohatej rodiny z Wuxi. Čast' svojho života strávil putovaním v člne jazernatou krajinou južnej Číny. Jeho malby sú zriedkavo farebné, tahy štetca sú zjednodušené, sú velmi jemná farebnost', kultivované. Majú atmosféru osamelosti (Zhongguo meishu jianshi, 1990, 152). „Moje takzvané malby nie sú v skutočnosti nič viac ako nespútané tahy štetca, volne načrtnuté, nie sú spojené s formálnou podobnostou (objektov v prírode), sú namalované iba pre moje osobné potešenie.“ Ked' jeden jeho priatel' vyhlásil, že jeho bambus sa vôbec nepodobá na bambus, odpovedal: „Ah, ale úplné chýbanie podobnosti nie je vôbec l'ahké dosiahnut!"“ (Cahill 1988, 88).

Jeho obrazy vždy zobrazovali niekolko stromov, príbytok z trávy, bez ludských postáv, bez pohybu (obr. 6). Ale práve v týchto bežných a jednoduchých scenériách prostredníctvom zjednodušených tahov štetca, vyjadril pocit bezmocnosti a lahkej melanchólie, určitý pocit osamelosti a mlčania akoby zem zostarla a nebo spustlo, načrtol krásu výraznú pocitu (Li Zehou 1982, 183).

Ďalší umelec, ktorého krajinomal'by nesú v sebe prvok abstraktného vyjadrovania, taoista Fang Congyi 方從義 (1302cca 1393), vynikal v mal'ovaní hôr ponorených do hmiel, ponáral sa do „tušových hier“. Jeho tahy štetcom sú mimoriadne zjednodušené, maloval až po dlhom procese sústredenia sa. Tento umelec „V niektorých svojich obrazoch vyzeral, akoby znova hral predstavenie skorších maliarov, ktorý vrhali tuš na papier (obr. 7). Kritici ho pochopitelne zaradili do kategórie yipin a videli jeho štýl ako priame vyjadrenie jeho taoistickej nadprirodzenosti. „Ako by to mohol urobit,“" pýtal

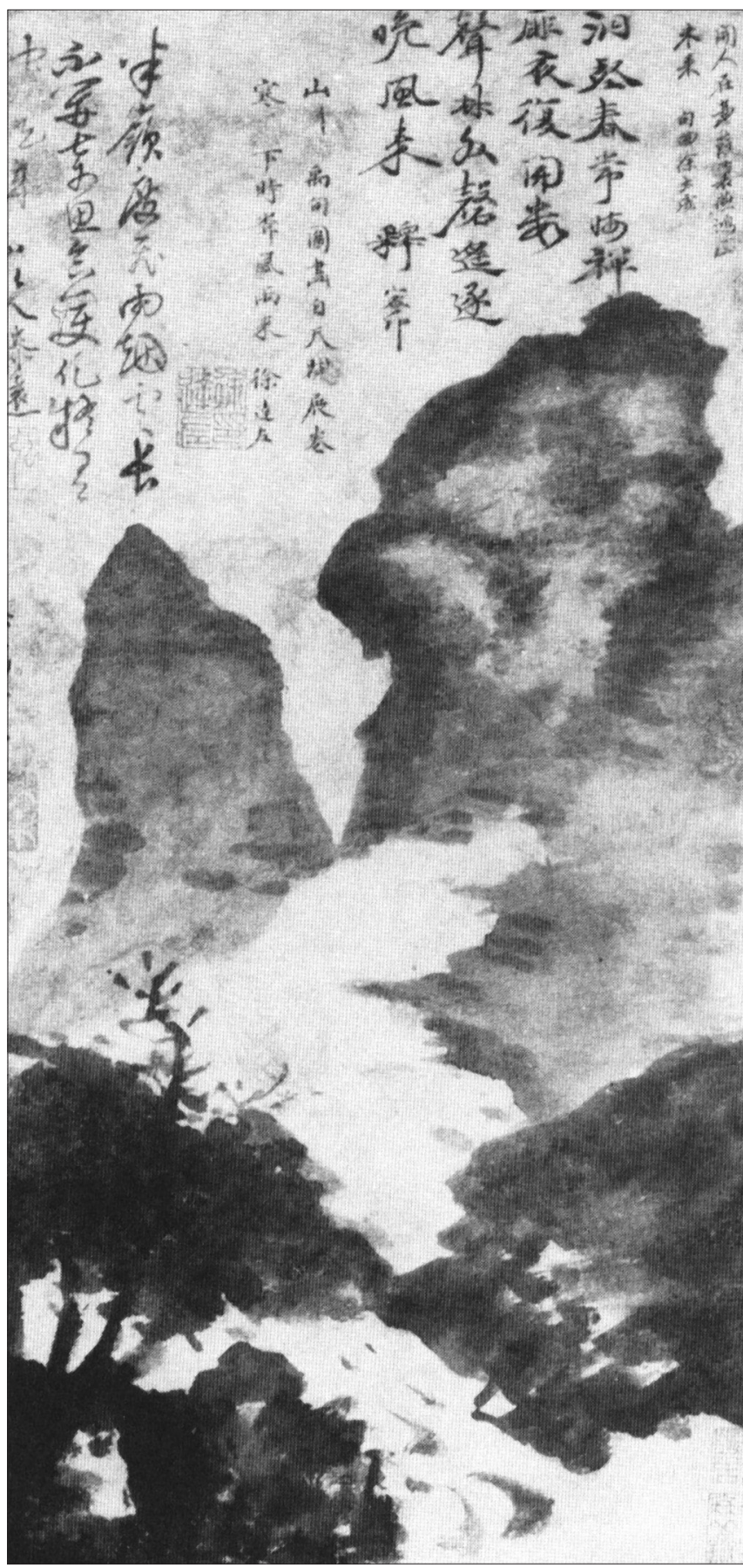

Obr. 7. Fang Congyi, Hory v oblakoch, dynastia Yuan.

sa jeden jeho súčasník, „ak nie je (taoistický) nesmrtelný?“ (Cahill 1988, 88-89).

Yuanská malba na základe rešpektovania tradície vytvorila nový zmyslel, nový štýl. Kaligrafické tahy vyniesla na velmi dôležité postavenie. Zavrhovala štýly, ktoré sa snažili o presné vykreslovanie tvaru, stavali na remeselnej zručnosti, snahou o presnú podobu, vonkajšiu. Formálnu podobnost xingsi odsunula na vedlajšie miesto. Zastávala názory 以神求貌 yi shen qiu mao „prostredníctvom espritu sa snažit” o vonkajšok veci“ 以逸為上yi yi wei shang „vysoké umenie postavila na najvyšší stupeň“ (Yang Renkai 1991, 391). 


\subsection{Malba dynastie Ming (1368-1644)}

Dynastia Ming je dôležitým obdobím v histórii maliarstva a kaligrafie. V malbe bola zastúpená Dai Jinom 戴進 ako predstavitelom školy Zhe, Shen Zhouom 沈周 a Wen Zhengmingom 文征明, ktorí reprezentujú školu Wu. Na začiatku dynastie vystupovali do popredia hlavne akademickí maliari napodobňujúci realistické songské maliarstvo. V strede a neskôr sa vrátil štýl wenren hua, ktorý nadviazal na yuanskú malbu literátov. Maliari-literáti opät zaujali vedúce postavenie (Yang Renkai 1991, 393). Dynastia Ming je obdobím, z ktorého máme pomerne vel'ké množstvo zachovaných obrazov, no aj iné materiály, napríklad poznámky umelcov o ich dielach a početné teoretické spisy.

Maliarstvo mingských učencov, podobne ako ich myslenie, smerovalo k tomu, aby sa stalo viac intuitívnym a zovšeobecneným, a ak ich predchodcovia naučili všetko, čo potrebovali vediet zo štúdia reálneho sveta, tak si iba „požičiavali“, ako to povedal Su Shi, hory a vodu, kamene a stromy ako nástroje, ktorými vyjadrovali svoje pocity. Mingské maliarstvo znamenalo zároveň viac a menej ako songské; menej v tom, čo hovorilo o prírode, a viac v tom zmysle, že maliarstvo nieslo ovela väčší batoh poetických a filozofických významov. Alebo, inými slovami, že autor hovoril veci, ktoré nemohli byt’ plne vyjadrené v termínoch konvenčnej krajinomalby. Pomáhalo to do takej miery, že Číňania umiestnili ideu mimo obrazu samotného, maliarove nápisy na obrazoch boli dlhšie a ovela bohatšie po poetickej a filozofickej stránke (podla: Sullivan 1977, 21)

V období Ming bola malba literátov wenren hua prvýkrát definovaná pod týmto názvom, ked' maliar, literát a výtvarný teoretik Dong Qichang 董其昌 (1555-1636) prišiel so svojou teóriou o severnej a južnej škole. Možno povedat', že v období dynastie Ming začalo maliarstvo klást väčší dôraz na subjektivitu, ktorá sa prejavovala nielen v úzkom okruhu vzdelaných literátov wenren, ale jej výdobytky boli postupne akceptované aj maliarmi z iných sociálnych vrstiev.

Tu treba poznamenat, že wenren hua býva v súčasnosti často chápaná aj ovela v širších súvislostiach, ako bola definovaná Dong Qichangom. Často sa pod týmto pojmom rozumie subjektívne ladená škola, ktorá kladie väčší dôraz na sebavyjadrenie než na formálnu reprezentáciu, teda tento pojem sa v širšom slova zmysle nevztahuje striktne len na malbu maliarov - učencov či úradníkov. Do takto rozšírenej definície wenren hua sa vmestí mnoho individualít, ktoré vo svojej dobe neboli považované za reprezentantov tejto školy. Pôvodná mal'ba literátov bola príliš úzko zviazaná s určitou skupinou ludí, hoci v čase svojho vzniku za dynastie Song bola vysoko progresívna, ale postupom času sa stala neprístupnou novým impulzom. Ako sa vyjadril Dong Qichang: „Někteří mají za to, že si má každý založit svoji školu. Ve skutečnosti tu není pro nic takového místa (...) Bylo by nesmyslné skutečně aspirovat na osobně pojatou tvorbu a přitom prrehlížet klasické metody. Berte to nejlepší z každého a pojměte je do svého díla" (Malírské rozpravy Mnicha Okurky, 1996, 23-24). Tým sa mnohí originálni maliari dostali do pozície neortodoxných, „divokých“.
V štýle a technike vyzerá že to, čo je nazývané „divokost“ sa začalo $\mathrm{v}$ neskorších alebo spontánnejších dielach Dai Jina a bolo rozvinuté v umení Wu Weia 吳偉, Lin Lianga 林良, Shi Honga, Xu Lina, rovnako ako u Zhang Fuyanga, Zong Liho, Jiang Songa 蔣嵩, Wang Zhaoa 汪肇, Zhang Lua 張路, Zhu Banga a iných. Umelci preferujúci tento štýl boli skoro všetci profesionálni majstri. Ako maliari boli opisovaní termínmi „útočiaci priamo“, „zúrivo narábali so štetcom“, „vrhali tuš na papier a nechali ho odkvapkávat" - čo naznačuje, že používali svoju profesionálnu zručnost’ v oblasti podobnej niečomu ako je čistý proces alebo spontánna tvorba. Ich techniky môžu byt' opísané niekolkými známymi termínmi („sekerovité tahy“, niekedy ako mi body, metóda „bez kostí“) ale vo všeobecnosti vyžadujú také vágne ekvivalenty ako „čmáranie" a „splašc (Barnhart, 1983, 370).

Mnohé z týchto malieb, označovaných pod pojmom „divoké“, sa svojou subjektivitou vo vyjadrovaní a vel'kou mierou štylizácie, približujú $\mathrm{k}$ abstraktnému maliarstvu dvadsiateho storočia. V skutočnosti je samotný pojem abstrakcia, či abstraktné umenie, termínom, ktorý sa objavil relatívne nedávno, a to najskôr v západných avantgardných hnutiach. Akonáhle sa $\mathrm{v}$ čínskych dejinách malby objavilo dielo, ktoré by sme dnešným slovníkom označili za semiabstraktné, jeho súčasníci mohli použit iba iné slová či výrazy ako „nespútaný realitou“, „oslobodený od tvaru“, „nevyjadrujúci vonkajšiu podobnost"“. Neortodoxný maliar Wu Wei (1459-1508), patriaci k Zhe škole, bol nazývaný aj Xiao Xian 小仙 (malý „svätec“, t. j. osoba vládnuca nadprirozdenými schopnostami). Jeho krajinomalba a figuralistika sú aj v štýle malby pracným štetcom, gongbi aj malbe hrubým, velkorysým štetcom cubi 粗筆. Na začiatku mal'oval postavy v štýle Li Gonglina. Jeho mal'ba velkým štetcom cubi má korene v Liang Kaiovej malbe. Wu Weiove vel'korysé malby krajiny a postáv v štýle xieyi sú nespútané, vel'kolepé, jeho tuš volne stekal po papieri (Yang Renkai, 1991, 420-421). Vo Wu Weiových mal'bách je badatelný prvok abstrakcie (obr. 8).

Ďalší predstavitel' Zhe školy, Lin Liang (cca 1436-1487), ktorý pochádzal zo súčasnej provincie Guangdong, mal'oval predovšetkým kvety a vtáky. Jeho vtáky boli načrtnuté vel'korysými pohybmi, pripomínajúce kaligrafické konceptné písmo caoshu. Maloval aj v štýle gongbi. Väčšina z jeho zachovaných prác sú mal'by v štýle xieyi (Yang Renkai 1991, 417). Vynikal v malovaní malby tušom v štýle xieyi, mal'oval najmä orly, jeho pohyby štetcom boli plné sily, prudké, maloval aj farebné motívy $\mathrm{v}$ štýle gongbi.

Medzi neortodoxných maliarov patril aj majster, žijúci začiatkom 16. storočia, Shi Hong. Bol excentrik a v neskorších rokoch nazýval sám seba Chi Weng, čo značí Starý blázon. Často opitý spieval a maloval krajinomalby splašovým impulzívnym štýlom podobným Wu Weiovi (Cahill, 1988, 90-91). Počas prosperujúcich rokov v strede dynastie Ming bol okres Wu umeleckým centrom Číny a Shen Zhou 沈周 (1427-1509) jeho najkrajším ornamentom. Takisto bol pokladaný za zakladatela školy $W u$, ale bol iba najdôležitejším z dlhej línie maliarov krajiny vo $W u$, v ktorej môžeme íst' až ku Zhang Zaovi z dynastie Tang (Sullivan, 1977, 215-216). Shen Zhou bol 
talentovaný maliar, malujúci trochu v štýle Ni Zana, no kým Ni Zanove obrazy boli osamelé, evokovali prázdny priestor bez ludí, Shen Zhou mal'oval postavy. V 16. storočí dominoval regiónu Wu Wen Zhengming (1470-1559). Iným dôležitým predstavitelom $W u$ školy bol Chen Chun 陳淳 (1483-1544), nazývaný aj Daofu 道复, ktorý pochádzal zo Suzhou a vynikal v mal'ovaní kvetov a vtákov. Jeho tahy štetcom boli slobodné, sledovali tok jeho myšlienok (Zhongguo meishu jianshi, 1990, 180). Práve on býval udávaný ako príklad abstrakcie v čínskych dejinách umenia.

V 17. storočí, teda na konci dynastie Ming a začiatkom dynastie Qing (1644-1911), došlo k d’alším zmenám v čínskom maliarstve, ktoré sú dôležité nielen $\mathrm{z}$ aspektu skrytej, tušenej abstrakcie, ale aj z hladiska celkového vývoja čínskeho maliarstva ako takého. K pádu dynastie Ming došlo v roku 1644, ale udalosti, ktoré zapríčinili jej pád, jej postupný úpadok, sa začal už dávno predtým, koncom 16. storočia. Konfuciánsky ideál služby štátu a spoločnosti sa už nemohol dlhšie udržat'. Individualistické filozofie, ako boli Li Zhi 李䞇 a Divokýzen, ktorý mal za ciel’ skôr osobnú sebarealizáciu ako sociálnu harmóniu, koexistovali so snahami o reformy a o návrat k základom konfucianizmu. Bol to vek protikladov a antitéz, extrémnych pozícii v myslení a umení (Cahill, 1982, 1-2).

Vel'ké výsledky zaznamenali predovšetkým maliari malujúci kvety, ktorých hlavným predstavitelom bol Xu Wei 徐渭 (1521-1593). Štetec a tuš sa v jeho podaní stali ešte „divokejšími“, prerazil niektoré pevne určené zásady. Ked' tvoril, mohutnými velkorysými pohybmi nanášal tuš, ktorý striekal a kvapkal všade navôkol. V jeho dielach sa prejavila výrazná umelecká osobnost'. Tento štýl v mal'be mal obrovský vplyv na stred Qing a posledných sto rokov v maliarstve (Yang Renkai, 1991, 396). Xu Wei bol všestranne talentovaný, vel'mi kultivovaný umelec. Vynikal aj v písaní kaligrafie konceptným štýlom kuangcao. Bol ovplyvnený novou vlnou snažiacou sa o oslobodenie osobnosti. Maloval kvety a vtáky vo velkorysom štýle xieyi, ktoré sú vel'mi osobitné. Jeho tahy štetcom pripomínajú kaligrafické tahy kuangcao, zaznamenávajú prudké záchvevy autorových emócií. Používal techniku vrhania tušu na papier (splaše), ktorý nechal odkvapkávat. Uprostred 似與 不似之間 si yu busi zhijian „podobania sa v nepodobnosti“ vo svojich obrazoch vyjadruje predovšetkým shengyun 生韻 „rytmus plný života“. Čínsku malbu kvetov a vtákov v štýle xieyi vyniesol na stupeň, kde dokáže priamo vyjadrit subjektívne pocity (Zhongguo meishu jianshi, 1990, 181). Inšpiroval sa malbou kvetov a vtákov v štýle xieyi školy $W u$ a Lin Lianga, ale nenechal sa spútat ich štýlom. Xu Weiove najradikálnejšie redukcie vizuálnej formy smerom ku kaligrafickým pohybom nás priniesla tak blízko k totálnej abstrakcii ako nič iné namalované pred ním (Cahill, 1988, 92).

Obr. 8. Xu Wei, Hrozno, 1666, 133x64,5 cm, tuš a voda na papieri, dynastia Ming, Múzeum Zakázaného mesta, Beijing. Na obraze vyjadruje svoj smútok z jeho neštastného života. Báseň vo vrchnej časti obrazu: ubehla polovica môjho života v zúfalej tiesni, som už starý. Stojím osamelo vo svojej pracovni, nočný vietor píska, perly z môjho stetca nemám kde predat', sú hodené do divokého viniča. Perla je metafora pre hrozno aj pre jeho prácu, v povzdychu, že jeho tvrdá práca a jeho umenie neboli ocenené.

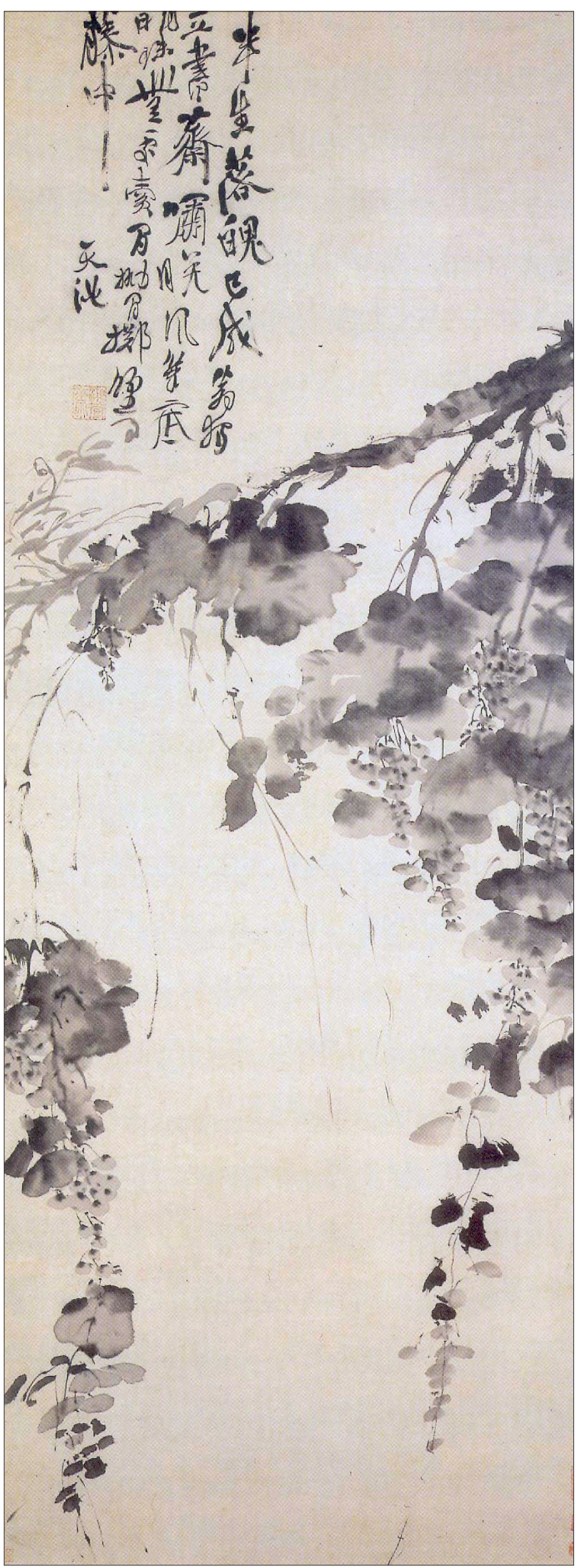




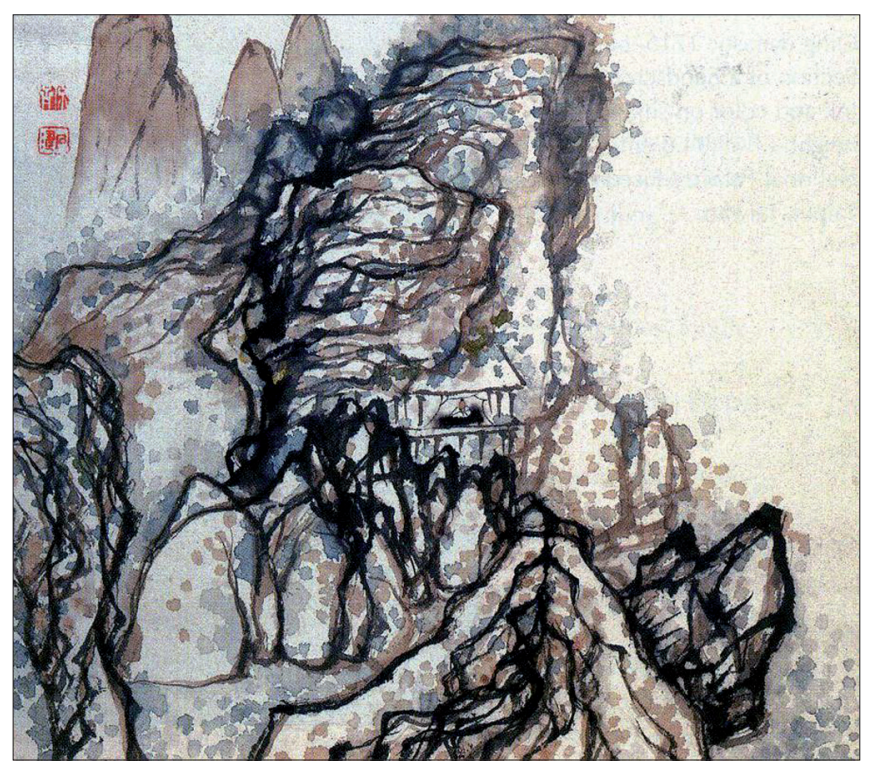

Obr. 9. Shitao, Spomienky na Qinhuai, 17. storočie.

\subsection{Dynastia Qing (1644-1911)}

V 17. storočí, na začiatku dynastie Qing, zaznamenalo čínske maliarstvo jeden zo svojich vrcholov, pokial' ide o expresivitu tvorby. Zatial' čo ortodoxná mal'ba literátov postupne strácala na životnosti, do popredia sa stále viac dostávali individualistickí umelci, existujúci mimo establishmentu, alebo aspoň nezávisle od neho.

$\mathrm{V}$ 17. storočí sa malba literátov postupne dostala na hlavné miesto v maliarstve. Populárne boli krajinomalba, ako aj tušová malba v štýle xieyi. Začiatkom Qing to boli maliari, neskôr nazývaní Štyria Wangovia; Wang Shimin 王時敏 (1592-1680), Wang Jian 王鑒(1598-1677), Wang Hui 王 翚 (1632-1717), Wang Yuanqi 王原祁 (1642-1715). Títo umelci zdôrazňovali predovšetkým napodobňovanie starých majstrov, vynikali vysokým technickým majstrovstvom, ale ich obsah ich diel postrádal životnosti. Naproti tomu, nezávislí maliari, tradične nazývaní Štyria mnísi, Hongren 引 仁 (1610-1663), Kuncan 䯳殘 (1612-1692), Shitao 石濤 (1641-1704), Zhu Da 朱目 (1626-1705), a Nankingská maliarska škola, medzi umelcami ktorej vyniká najmä Gong Xian 龔賢(1618-1689), zdôrazňovali v umení vyjadrenie osobnosti, protestovali proti presným vzorom, ktoré sa prenášali z generácie na generáciu. Ich práce boli plné citu, výrazné, štýl bol osobitý (Yang Renkai 1991, 505).

V období Qing, v malbách počnúc Shitao, Zhu Da až po Yanzhouskú maliarsku školu 18. storočia, známejšiu pod názvom Osem čudákov z Yangzhou, vonkajšia, tvarová podobnost’ xingsi bola opät na krok opustená. Subjektívne idey, pocity, vnemy zatlačili všetko. Umelcova osobnost', jej špecifiká, boli zdôrazňované stále viac (Li Zehou, 1982, 185).

Jedným z nezávislých maliarov bol mingský loajalista Hongren (1610-1663). Pochádzal z provincie Anhui, po páde dynastie Ming odišiel do hôr a stal sa mníchom. Od detstva mal rád literatúru a malbu. Maloval najmä krajinomalby. V mnohých aspektoch vychádzal z Ni Zanových diel, jeho kompozícia je velmi zjednodušená, nebol spútaný starými spôsobmi mal'by, často používal suchý štetec. Preslávil sa mal'bami hory Huangshan. Hovorí sa o ňom, že 得黃山之真性情 de Huangshan zhi zhen xing qing „pochopil skutočnú povahu a pocity hory Huangshan“ (Yang Renkai 1991, 533-535). V jeho malbe hory Wuyi „na jednej strane, malovanie je abstraktnou konštrukciou s vel'kou komplexnostou (...) na druhej strane, ako nám vraví umelec, ide o určitý druh reprezentácie niečoho, čo videl a zapamätal si popri rieke Deviatich zákrut vo Fujian" (Cahill, 1982, 5).

Najoriginálnejších maliarov týchto desatročí (koniec Ming, začiatok Qing), niekedy nazývaných aj školou Individualistov, nachádzame medzi buddhistickými mníchmi; vniesli nový život do tradície zenového štýlu. Je to Zhu Da 朱目 (mníšskym menom Badashanren 八大山人), ktorého tu spomínam ani nie pre jeho krajinomalby (hoci ani tie neboli skutočne konvenčné), ako pre jeho malby kvetov a vtákov tušovou technikou. Vedel, ako sa sústredit' na podstatné a vyjadrit’ seba pomocou tak málo prostriedkov ako je to len možné. Takisto vedel ako dokáže prázdna plocha na obraze byt’ výrečnou. Mních Shitao bol nielen mimoriadny maliar ale aj vynikajúci spisovatel. Bol jedným z prvých, ktorí protestovali proti nekonečnému imitovaniu starých majstrov. Jeho obrazy ukazujú podobný postoj (Cohn, 1951, 100).

Shitao (1641-1704), nazývaný aj Mních Horká uhorka (Kugua heshang 苦瓜和尚), bol, rovnako ako Badashanren, silne ovplyvnený Xu Weiovým vyjadrovaním umeleckej osobnosti. Obaja pozorovali prírodu, neobmedzovali sa kopírovaním starých majstrov, neprijali obmedzenia starých techník. Spájali objektívne so subjektívnym, 尚意 shangyi „zdôrazňovali vyjadrenie ideí“. Pretrhali staré výtvarné postupy, nechali básne a kaligrafiu vstúpit do mal'by, rozvíjali techniku tušu. Ich umenie malo v tom období hlboký tvorivý impulz (Zhongguo meishu jianshi, 1990, 186). Badashanrenove a Shitaove malby kvetov a vtákov v štýle xieyi znamenali nový vývoj v tvorbe tvarov, kompozícii, v práci so štetcom a tušom (Zhongguo meishu jianshi, 1990, 187).

Shitao bol maliar - individualista, ktorý položil základy moderného čínskeho umenia. Bol priamym potomkom dynastie Ming. Po páde dynastie sa potuloval v okolí buddhistických kláštorov, no nebol mníchom v pravom zmysle slova. Nejaký čas žil v Nankingu v neskorších rokoch sa napokon usadil v Yangzhou, kde sa stal profesionálnym, no vysoko rešpektovaným maliarom. Jeho neskoré práce sú prekvapujúco moderné, s nádychom expresie (obr. 9). Hoci bol hlboko ovplyvnený zen buddhistickými myšlienkami, zdá sa, že sa nikdy úplne nepodriadil kláštorným regulám. Niektoré jeho mal'by ponúkajú brilantné príklady používania tušu, farby a štetca, sú riskantné ale úplne úspešné (Cahill, 1982, 218-219).Čoraz viac sa odkláňal od zaužívaných tradícií. Vo svojich mal'bách ako aj v teoretických úvahách zdôrazñuje vyjadrenie osobnosti, originalitu, nezávislost' od starých vzorov. V Shitaových dielach $\mathrm{z}$ posledných rokov vidíme príklon $\mathrm{k}$ umeleckému subjektívnemu vyjadrovaniu stojacemu na rozhraní abstrak- 


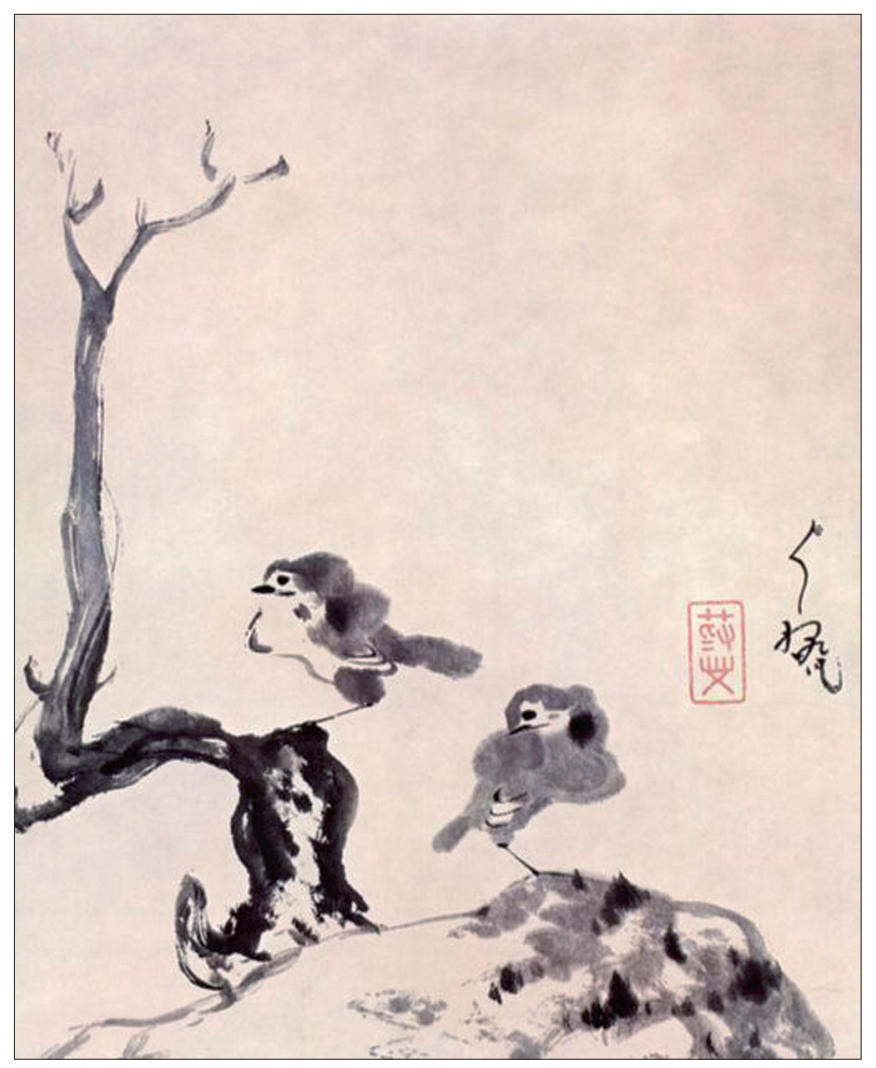

Obr. 10. Zhu Da, Vtáky, 17. storočie.

cie, slobodnej hry s čiarami, kde je vonkajšia podobnost', či náznak krajiny sotva badatelný, a možno z hladiska samotného diela už ani nie príliš dôležitý. Silný príklon k abstrakcii sa prejavuje najmä na obrazoch $\mathrm{z}$ neskorého obdobia. K najvýraznejším ukážkam tohto štýlu patrí napríklad dielo Desattisíc škaredých tušových bodov.

Zhu Da, známejší pod menom Badashanren (1626-1705), pochádzal z provincie Jiangxi, Nanchang. Mnohé jeho malby vyjadrujú osobné pocity autora prostredníctvom požičiavania si tvarov, ktoré maloval. Prostredníctvom symbolov vyjadril skrytý zmysel. Personifikoval objekty svojej malby, vyjadril svoje pocity, city, emócie. V jeho dielach je velký podiel subjektívneho. Napríklad oči jeho rýb a vtákov 白眼向人 bai yan xiang ren "akoby pozerali na diváka“ (obr. 10)., vyjadrujúc umelcovu nespokojnost' so svetom, s jeho nízkostou a vulgárnostou (Yang Renkai, 1991, 529). Niektoré maximálne zjednodušené, niekolkými tahmi načrtnuté kvety sa už blížia $\mathrm{k}$ abstraktnej malbe (obr. 11).

Tretí maliar - mních, Kuncan (1612-1673?), dal buddhistickej koncepcii úplne nový aspekt. Kuncan, nazývaný aj Shixi, ktorý sa stal mníchom v roku 1651, maloval figúry, krajinu, ako aj kvetinové zátišia. Jeho tahy štetca boli hrubé a pevné, plné sily, jeho technika bola mohutná, vel'korysá, jednoduchá, tahy štetca boli zjednodušené. Často pri malovaní používal suchý štetec s trochou tušu. Vo svojej tvorbe zhrnul pocity a nálady maliarov rozličných období. Bol vo svojej dobe vysoko originálny(Yang Renkai, 1991, 531-533). V jeho diele

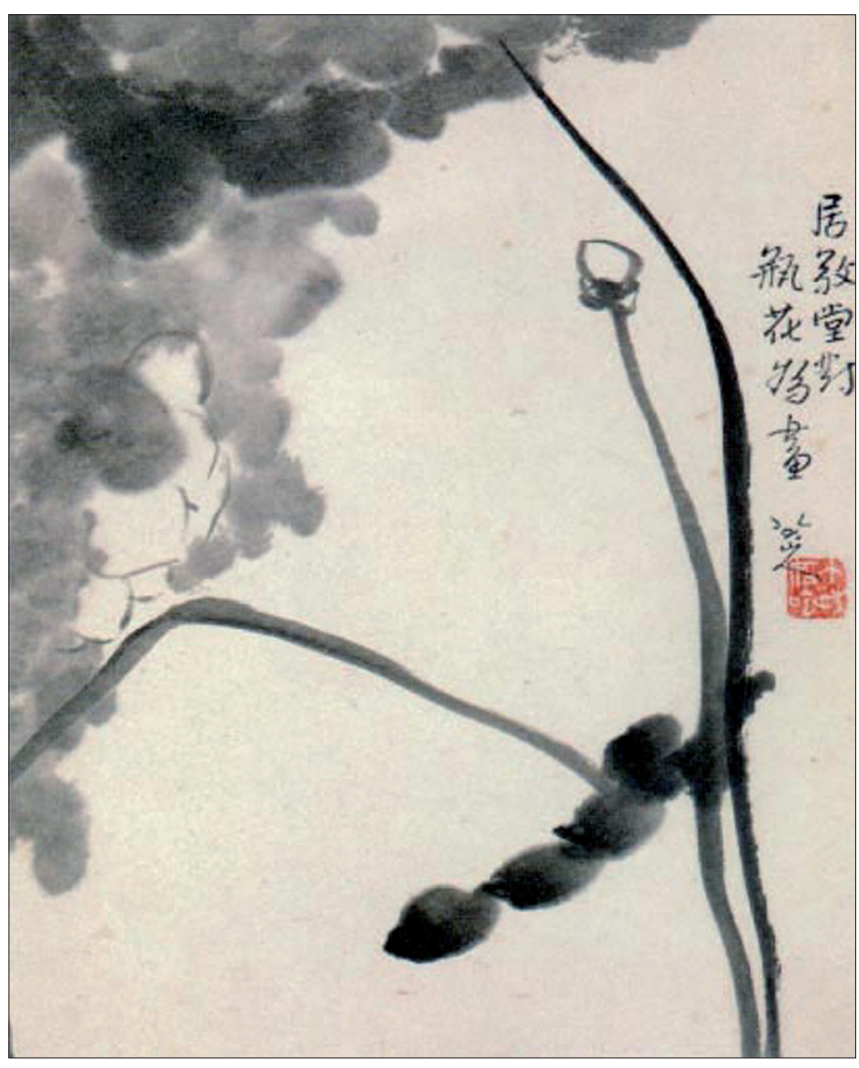

Obr. 11. Zhu Da, Lotos, 17. storočie.

Buddha v pustatine je pozadie tvorené mohutnými horskými drevinami, ktoré sú namalované vitálnymi dotykmi štetca. Ale prítomnost' Osvietenia leží vo vzduchu tajomnosti scenérie (Cohn, 1951, 100-101).

Iný významný qingský maliar, Gao Qipei (1660-1734), maloval postavy, krajiny, kvety a vtáky. Vynikal v používaní štýlu xieyi. Maloval prstami. Niektoré jeho diela sú pomerne abstraktné (vol’ne podla: Yang Renkai, 1991, 565).

Začiatkom osemnásteho storočia sa spolu s oživením a vývojom spoločnosti, vyvíjali sa obchodné mestá, národnostné rozpory medzi Číňanmi a Mandžuami sa zmenšili, začali sa rozvíjat' mnohé rozličné názory a kultúra s určitými črtami počiatočnej demokracie. Pod vplyvom Shitaa a iných maliarov s výraznými prvkami osobnosti, výraznej individuality sa prosperujúce obchodné mesto Yangzhou, s pomerne živými myšlienkovými prúdmi zmenilo na pulzujúce umelecké centrum, kde existoval trh s umeleckými dielami. Toto mesto pritahovalo mnohých umelcov rôznych umeleckých smerov. Najslávnejšia je Yangzhouská maliarska škola 18. storočia, známejšia ako Osem čudákov z Yangzhou (volne podla: Zhongguo meishu jianshi, 1990, 189). V umeleckých kruhoch sa v 18. storočí odohrala premena, ktorá reflektovala zmeny v spoločenských a estetických názoroch. Napriek tomu, že napríklad každý z Osmych čudákov mal svoj osobitný štýl, môžeme si všimnút aj niektoré spoločné umelecké črty. Je to predovšetkým vyjadrenie osobnosti, využívanie vlastnej umeleckej metódy, preferovanie štýlu xieyi, čo znamená vyjadrenie duchov- 
nej podstaty, zdôrazňovanie ideovej, vnútornej podobnosti s mal'ovaným objektom shensi, dôraz na autorovu morálku, osobnost' a umeleckú kultivovanost' (vol'ne podla: Zhongguo meishu jianshi, 1990, 191).

Osem čudákov z Yangzhou, boli niekol'kí maliari, ktorí žili v Yangzhou a okolí. Nie je presne známe, ktorí maliari patrili medzi tých ôsmych, ktorých spomínajú čínske pramene, údaje sa rôznia. Väčšinou sa tvrdí, že to boli Jin Nong 金農 (1687-1764), Huang Shen 黃慎 (1687-?1770), Zheng Xie 鄭 﨎 (1693-1765), známejší pod menom Zheng Banqiao 鄭板 橋, Li Shan 李鱛 (1686-1762), Li Fangying 李方鷹 (16961755), Wang Shishen 汪士慎 (1686-1759), Gao Xiang 高翔 (1688-1753), ktorého tvorba s prvkami abstrakcie mala vela spoločné s literátskou malbou a Luo Pin 羅聘 (1733-1799). Osem čudákov využíva v umení rozličné výrazové prostriedky, každý má svoj osobitný výraz, ale majú aj vel’a spoločných čŕt. Preto vytvorili silný umelecký prúd. Všetci mali podobné životné skúsenosti, názory a pocity. Väčšina z nich pochádzala $\mathrm{z}$ rodín intelektuálov, niektorí zložili štátne skúšky a nejakú dobu zastávali úradnícky post, ale v konečnom dôsledku sa živili predajom svojich obrazov. Zdôrazňovali originalitu $\mathrm{v}$ umeleckej tvorbe, vo vztahu $\mathrm{k}$ vonkajšiemu tvaru, forme xing a espritu, shen, zdôrazňovali esprit. Vynikali v monochromatickej malbe v štýle xieyi. Ich obrazy vyjadrovali výrazné subjektívne pocity. Kládli dôraz na prepojenie malby, poézie a kaligrafie, pričom zdôrazňovali kaligrafické tahy v malbe (Yang Renkai 1991, 546-547). Sila mnohých z nich ležala práve v ich kaligrafii.

Umenie Yangzhouskej školy 18. storočia nesie hlboké idey, výraznú pečat autorskej osobnosti, bláznivé a vel'korysé umelecké tóny. Svojimi obrazmi vyjadrovali svoje pocity tiesne, hrdú povahu, výrazne vyjadrovali svoju osobnost'. Ich diela sú naplnené intenzívnym citom. Neboli spútaní jednotným štýlom mal'by. Boli blázniví, čudní, odlišní, používali techniku da xieyi. Ich tvorba mala výrazný vplyv na neskorší vývoj malby v štýle xieyi, ako aj na malbu kvetov a vtákov až do súčasnosti. Najznámejší z ôsmych čudákov je kaligraf Zheng Xie (16931765), nazývaný aj Zheng Banqiao. Vynikal v malovaní kameňov, bambusu, orchideí, najlepšie maloval tušové bambusy. Štýl malby sa učil od individualistických maliarov ako boli Xu Wei, Shitao a Zhu Da. Mimoriadne silne vyjadroval v kaligrafických nápisoch svoje 真性情, 真意氣zhen xingqing, zhen yi qi „skutočné pocity, skutočný zmysel a esprit“. Jeho bambusy sú jeho vyjadrením jeho názorov a osobnosti, morálky. Mali špecifickú osamelú a hrdú povahu, cit pre spravodlivost'. V umení zdôrazňoval, že意在筆先yi zai bi xian „idea predchádza štetcu“ (Yang Renkai 1991, 549-550).

Ďalší spomedzi ôsmych čudákov, Jin Nong (1687-1764) vo svojej dobe bol vel'mi vysoko hodnotený a vel'mi známy. Vynikal predovšetkým v kaligrafii. Okrem toho maloval krajiny, figuralistiku, kvety a vtáky. Bol známy svojimi tušovými kvetmi meihua (slivy). Prednostou jeho krajinomalby bol yijing, prenos ideí. Jeho mal'by boli jednoduché, dojímali svojou akoby detskou úprimnostou a zámernou neohrabanostou. Jin Nongove obrazy mali silný básnický náboj, mimo obrazu. Postavy v jeho podaní boli akoby nedbalé, nezále- žalo mu na vonkajšej podobe (Yang Renkai 1991, 549-550). Huang Shen (1687-1770?) pochádzal z provincie Fujian, vynikal v malovaní postáv, po svojom príchode do Yangzhou rozvíjal figuralistiku v štýle da xieyi. Vo svojich obrazoch používal tahy štetca typické pre kaligrafiu kuangcao, ktorú sám písal. Maloval bláznivo, rýchlymi vel'korysými pohybmi, jeho malby boli plné vnútornej energie (Zhongguo meishu jianshi 1990, 191).

Ďalší z yangzhouských maliarov, Li Shan (1686-1762), pochádzal z provincie Jiangsu. Od detstva maloval, vo svojich 16-17 rokoch bol už uznávaný maliar. Učil sa od Gao Qipei, slávneho prstového maliara, ale bral inšpiráciu aj od Shitao, ktorý takisto žil v Yangzhou. Používal zničený štetec a pri malovaní vrhal tuš na papier (pomo 潑墨). Neobmedzoval sa technikou, nesnažil sa o vonkajšiu tvarovú podobnost'. Vo výtvarnom svete bol rovnako slávny ako Jin Nong (Yang Renkai 1991, 550).

\subsection{Vývoj maliarstva v 19. storočí}

V strede 19. storočia sa prístavné mesto Šanghaj stalo ekonomicky prudko sa rozvíjajúcim vel'komestom, kde sa vytvoril nový trh s výtvarným umením. Atmosféra vel'komesta spolu s ekonomickou prosperitou pritiahli do Šanghaje maliarov z okolia. Vytvorila sa Šanghajská škola (Haipai 海派). Táto škola nadviazala na tradíciu literárnej malby, spájajúcej mal'bu, poéziu a kaligrafiu do jedného celku, ktorú kombinovala s jasnými farbami, typickými pre ludové umenie.

Medzi najdôležitejších predstavitelov Šanghajskej školy patria Ren Xiong 任熊 (1823-1857, Ren Xun 任薰 (1835-1893), Ren Yi 仁頣 (1840-1895), známy aj ako Ren Bonian 任伯 年, Xugu 虛谷 (1824-1896), ako aj Wu Changshuo 吳昌碩 (1844-1927) a Zhao Zhiqian 趙之謙, ktorí bývali označovaní aj za epigrafickú školu. Mal'ba posledných dvoch mala prvky literátskej malby. Nadviazali na tradíciu malby xieyi kvetov ktorú rozvinul Xu Wei. Do mal'by vniesli tahy typické pre kaligrafiu a pre vyrezávané pečate. Otvorili novú cestu pre mal'bu literátov (Yang Renkai 1991, 506-507).

Významný predstavitel' Šanghajskej školy, bol Wu Changshuo (1844-1927), o ktorom sa niekedy hovorí ako o poslednom predstavitelovi maliarov-literátov. Wu Changshuo bol maliar a kaligraf, rád písal básne. Preslávil sa ako maliar kvetov vo velkorysej mal'be štýlu xieyi. Nadviazal tradície na umenia Chen Chuna, Xu Weia, Shitaa, Badashanrena, Jin Nonga, Li Shana a Li Fangyinga. Takisto bol ovplyvnený Zhao Zhiqianom a Ren Yi. Často používal tahy, bežné u kaligrafie typu pečatného písma 管文 zhuanwen na malovanie slív, tahy bláznivej kaligrafie kuangcao na hroznové úponky. Spojil prirodzený vzhlad predmetu mal'by so svojimi subjektívnymi predstavami a dojmami. Jeho štýl malby mal vel'ký vplyv na mal'bu moderných aj súčasných čínskych maliarov (Yang Renkai, 1991, 580). Pri používaní tušu vedel vynikajúco využit jeho výrazové prostriedky, husté, riedke, suché a mokré tahy, vyjadrit’ nimi vnútornú povahu a životnost' objektu, shengyun, ktorý presahuje vonkajšiu podobnost' objektu (Zhongguo me- 
ishu jianshi, 1990, 234). Jeho obrazy nám ukazujú nie obrazy prírody, ale zátišia $\mathrm{z}$ rastlín a kameňov $\mathrm{v}$ abstraktnom priestore, obrazy, ktoré môžu byt ponímané ako štruktúry disciplinovaných tahov štetca, vyhýbajúce sa dotyku zo zemou (Cahill, in Kao Mayching, 1988, 69). Wu Changshuo svojimi dielami už predznamenával čínsku modernu, ktorá výraznou mierou nadväzuje práve na jeho tvorbu.

\section{ZÁVER}

Aj v uvedenom vel’mi stručnom prehlade čínskych dejín maliarstva si možno všimnút, že popri dielach, ktoré zdôrazňovali vonkajšiu podobu malby s objektom, je subjektivita a snaha o sebavyjadrenie $\mathrm{v}$ čínskom maliarstve niečo vel'mi staré. Subjektivita ako taká sa prejavuje azda v každom historickom období svetových dejín maliarstva, ale sotva zanechala také hlboké stopy ako práve v čínskom maliarstve. Snahu o vyjadrenie emócií, autorových najvnútornejších pocitov, požičiavanie si formy predmetov na prejavenie svojich najhlbších pocitov, nachádzame u mnohých čínskych maliaroch vo vyhrotenej podobe. Ak práve tieto elementy boli v minulosti dôvodom vzájomného nepochopenia medzi východným a západným maliarstvom, kde Západ zdôrazňoval presnú podobu, vedeckú perspektívu, kým maliarstvo Východu sa nechalo často unášat slobodnými, nespútanými tahmi štetca, zabudnúc pritom na vonkajšiu podobu, v súčasnosti je to práve tento aspekt starého čínskeho maliarstva, ktorý je blízky nielen ideám moderny, ale aj celkovému pocitu, ktorý sprevádza súčasné svetové maliarstvo.

Kvalita umeleckého diela nemôžu byt merané podla času, ktorý nad ním tvorca strávil a ak uznáme, že báseň môže vzniknút v okamihu prudkého citového vzletu, vzplanutia, niet dôvodu, prečo by sme mali upriet' maliarstvu podobnú spontánnost'. Presnost' a podobnost' realite nie sú najdôležitejšie atribúty umeleckého diela, neboli nimi ani v obdobiach, ked' sa od umelca vyžadovali. Leonardove obrazy nás neuchvacujú preto, že ich autor študoval ludskú anatómiu, hoci sa stal známym aj svojimi anatomickými štúdiami, ale bez svojho talentu by sa určite nezapísal tak hlboko do dejín. V umení existuje niečo, čo je slovami dost̉ tažko vysvetlit', no starí čínski výtvarní teoretici si všimli ten rozdiel medzi púhou napodobeninou prírody, nie velmi odlišnou od fotografie a umeleckým dielom, ktoré je vynikajúce bez ohl’adu, či verne zobrazuje objekt, alebo ho nanovo tvorí na papieri - a možno celkom inak ako vyzerá v skutočnosti; to, čo vzniká, je nová skutočnost'. V umení je dôležitá aj krása rýchlosti, ktorá je tiež jednou z estetických kategórií, ktorá sa v čínskej výtvarnej tradícii prejavila rovnako vo vel'korysých splašoch a malbách xieyi ako v rýchlych líniách kaligrafie.

V subjektívnom videní čínskeho výtvarného umenia nachádzame výraznú predzvest' niečoho, čo sa vo svetovom umení naplno prejavilo až $\mathrm{v}$ dvadsiatom storočí, $\mathrm{v}$ prácach abstraktných maliarov, predovšetkým pokial' ide o smery, ktoré sú charakterizované viac expresivitou línie ako vedeckými poznatkami. Tým mám na mysli predovšetkým abstraktný expresionizmus, ktorý má vela spoločných čŕt s čínskymi splašmi a malbami v štýle da xieyi, ktoré sú štylizované až na hranicu abstrakcie. Podobnú snahu nachádzame aj u mnohých informelových maliarov, či iných prúdov abstrakcie snahu o oslobodenie línie od povinnosti zobrazovat', aby sa sama o sebe stala nositelom emócií. Podobne ako vo výtvarnej teórii, aj v samotnom maliarskom prejave dospelo tradičné čínske maliarstvo až na pokraj abstrakcie, z ktorej by azda mohlo, za iných historických okolností, prejst’ priamo k abstrakcii v pravom slova zmysle, bez reliktu zobrazovanej reality. No vývoj v čínskom umení sa uberal celkom iným smerom a tak sa o čisto abstraktnom maliarstve v čínskom kultúrnom prostredí dá hovorit až ovela neskôr.

\section{LITERATÚRA}

Barnhart, Richard (1983): The "Wild and Heterodox School" of Ming Painting. In: Bush, S. - Murck, C., eds., Theories of the Arts in China. New Jersey: Princeton University Press, 365-396.

Cahill, James (1988): The Shanghai School in Later Chinese Painting. In: Kao Mayching, ed., Twentieth-century Chinese Painting. Hong Kong: Oxford University Press.

Cahill, James (1976): Hills Beyond a River, Chinese Painting of the Yuan Dynasty. New York: Weatherhill.

Cahill, James (1982): The Compelling Image, Nature and Style in $17^{\text {th }}$-century Chinese Painting. Cambridge, MA: Harvard University Press.

Cahill, James (1988): Three Alternative Histories of Chinese Painting. Kansas: The Spencer Museum of Art, University of Kansas.

Cahill, James, in Kao Mayching (1988): Twentieth-century Chinese Painting. Hong Kong: Oxford University Press.

Cohn, William (1951): Chinese Painting. London: Phaidon Press.

Deng Fuxing (1986): Qiantan zhongguo hua de gediao. Zhongguo shuhua, $18,18-25$.

Fong, Wen C. (1992): Beyond Representation, Chinese Painting and Caligraphy $8^{\text {th }}-14^{\text {th }}$ Century. New York: The Metropolitan Museum of Art.

Ge Lu (1983): Zhongguo gudai huihua lilun fazhan shi. Shanghai: Shanghai renmin meishu chubanshe.

Hájek, Lubor, (2001): O osmi čínských „ošklivých obrazech“ ze zbírky Národní galerie. Revolver Revue, 45, 256-278.

Li Zehou (1982): Mei de licheng. Beijing: Wenwu chubanshe.

Lu Hong (1985): Cong xifang huihua zhong xishou xie shenme. Meishu sichao, 1, 20-25.

Malírské rozpravy Mnicha Okurky (1996): Překlad a komentáře Oldřich Král. Olomouc, Votobia.

Nelson, Susan, E. (1983): I-p'in in Later Criticism. In: Bush, Susan - Murck, Christian, eds., Theories of the Arts in China. New Jersey: Princeton University Press, 397-424.

Sullivan, Michael (1973): The Meeting of Eastern and Western Art from the Sixteen Century to the Present Day. Greenwich, CT: New York Graphic Society.

Sullivan, Michael (1977): The Arts of China. Berkeley: University of California Press.

Wang Xuelin - Xue Feng, eds. (1985): Jianming meishu cidian. Harbin: Heilongjiang renmin meishu chubanshe.

Wang Yao-ting (1996): Looking at Chinese Painting. Tokyo: Ningensha Publishing.

Xue Yongnian (1992): Shu hua shi lun conggao. Chengdu: Sichuan yishu chubanshe.

Yang Renkai, ed. (1991): Zhongguo shu hua. Shanghai: Shanghai guji chubanshe.

Zhongguo meishu cidian (1991): Shanghai: Shanghai meishu chubanshe.

Zhongguo meishu jianshi (1990): Beijing: Zhongyang meishu xueyuan meishushi xi, Zhongguo meishushi jiaoyanshi, Gaodeng jiaoyu chubanshe. 


\section{AUTORKA}

Zhang Cziráková, Daniela (1. 12. 1968, Bratislava), slovenská sinologička a výtvarníčka; pracuje na Ústave orientalistiky Slovenskej akadémie vied v Bratislave. Získala doktorát na Ústave Dálného východu, Filozofická fakulta, Univerzita Karlova v Prahe (2002). Študovala čínsku malbu na Centrálnej akadémii výtvarných umení, Peking (1992-1993 a 2002-2003). Predmetom jej vedeckého záujmu je čínske umenie. Zaujíma sa aj o súčasnú čínsku literatúru, hlavne o poéziu. Jej prednášky z dejín čínskeho umenia na Vysokej škole výtvarných umení v Bratislave a inde sa zameriavajú na kultúrnohistorický aspekt čínskeho umenia v širších spoločenských a filozo- fických súvislostiach. Publikuje články a štúdie týkajúce sa čínskeho umenia, čínskej filozofie a aj celkovo problematiky čínskej kultúry, preklady čínskej literatúry, aj vlastné literárne eseje, takisto s čínskou tématikou. Jej esej Pohlad zvonka - Nietzscheho Tak povedal Zarathustra a Lao c’ho Tao Te Ťing získala v roku 1998 2. cenu v Tvorivej sútaži o najlepšiu vedeckú esej (Romboid, 3, 1999). Diplomová práca: Kôñ a jeho symbolika v diele maliara Sü Pej-hunga (1994), dizertačná práca: Proces formovania abstrakcie $v$ súčasnom čínskom maliarstve (2001).

Kontakt: Mgr. Daniela Zhang Cziráková, Ph.D, Ústav orientalistiky Slovenskej akadémie vied, Klemensova 19, 81103 Bratislava, e-mail: danielazhang@hotmail.com. 